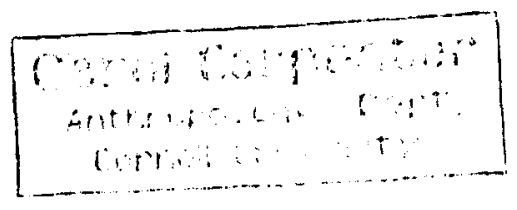

CIA STAFF PAPER

NO. 34

\title{
AFGHANISTAN: A DEMOGRAPHIC PROFILE
}

\author{
by
}

FRANK B. HORRS

Asia, Europe, North America, and Dceania Rranch

Center for International Research

Bureau of the Census

11.S. Department of Commerce

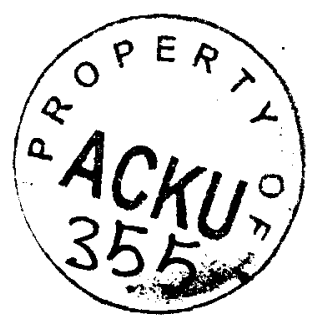

Washington, ก.C. 202.33

(301) 763-4221

January 1988 
SIJMMARY

Overview

Afghanistan, with a current population of $14,184,000$, is one of only a handful of countries in the world with a smaller population in 1937 than in 1980. This situation has occurred because of the ext-emely high volume of refugee movement from Afghanistan to Iran and Pakistan. More persons (over 4 million) fled Afghantstan during the 1979 to 1986 period than the total population of Norway.

Demographically. Afghanistan has the unenviable distinction of ranking among the "top" (or bottom) 10 countries of the world along several dimensions. For example, among all the world's countrles in the 1980's, Afghanistan had:

- One of the 10 highest crude death rates.

- One of the 10 lowest life expectancies at birth.

- One of the 10 lowest growth rates.

- One of the 10 highest infant mortality rates.

- One of the 10 highest net enigration rates.

- One of the 10 highest crude birth rates.

- One of the 10 lowest percentages of the population ages 55 years and over.

This report detalls the projected demographic picture of the population of Afghanistan, specifically covering the components of population change; namely, fertllity, mortality, and migration. In addition, a brief view of selected soctal and economic conditions is presented. The reader should bear in mind that the results depicted are the product of an analysis of all avallable demographic infomation. plus various assumptions as to how the separate components of population change may vary in the future. Particular attention should be given to the assumptions regarding the refugee population. These assumptions are meant to be fllustrative as to how the demography of afghanistan would be affected by alternative refugee movernent trends, rather than to be predictive. Some of the more notable outcomes of the component projections are detailed below.

Pof: "in stze

To pu. ghanistan's population size and area into perspective, the population of the total country is approximately that of the 1980 population of Texas and occuples an area slightly smaller than Texas. Afghanistan ranks 5nth among the countries of the world in total population size. Even though Afghanistan has a very high fertility rate, some of the consequences of the refugee movement on the total population size of the country are listed below: 
- After the Soviet invasion, the total population declined each year from 9980 to 1982 .

- The total population will not reach the pre-invasion level again until 1990 .

If the return of the refugee population to Afghanistan proceeds according to the medium series assumptions, the following population changes will occur:

- Afghanistan's population will double within 20 years.

- The total population will be growing faster during the 1990-95 period than that of 95 percent of the countries of the world. (This is in contrast to the 1980-85 perind, when the total population grew slower than that of 95 percent of the countries of the world).

Fertility

On the average, an Afghan woman will give birth to about seven children. This high rate of fertility implies that:

- One of every five Afghan women in the childbearing ages will give birth this year.

- Twice as many births occur in one year as deaths.

In addition to presently having a high total fertility rate (TFR). Afghanistan is projected to be among the slowest-rate-of-fertility-decline countries in the future. While many countries with high fertility rates promote the goal of lower growth rates through policies and/or programs to directly reduce fertility, Afghanistan's policy concentrates on mortality reduction, with family planning programs integrated within a maternal and child health program.

Mortality

A baby born in Afghanistan today can expect to live, on the average, about 4 ? years under present mortality conditions. This is one of the lowest life expectancies at birth in the world. Afghanistan, like several other countries in the Middle South Asian region of the world, also is characterized by a higher life expectancy at birth for males than for females. Mortality change in Afghanistan is not anticipated to be rapid. By the year 2050, the 1ife expectancy at birth projected for Afghanistan ( 70 years) is approximately the level achieved by the United States in 1965 (a lag of 85 years). On the average, a baby born in Afghanistan in 1987 could expect to live about the same number of years as: 
- A baby torn in Africa in 1950-65.

- A person in the United States that is 35 years of age.

As noted earlier, Afghanistan has one of the highest infant mortality rates in the world. One of every six bables born in Afghanistan will die before reaching its first $h$ irtnday. Since Afghan women bear an average of seven children, this implies that the average afgnan woman experiences the death of a child in infancy Although Afghanistan's population size and area are approximately equal to those of Texas, consider the following comparisons for 1986:

- 36 times as many infant deaths occurred in Afghanistan than in Texas, or 311 infants died each day in Afghanistan; 9 per day, in Texas.

- Afghanistan has nearly 3 times as many infant deaths as the entire United States, although the U.S. has about 16 times as many people as Afghanistan.

\section{Migration}

Internal migration in Afghanistan has traditionally been slight. In 1972-73, 12 out of every 13 native-born Afghans were living in their province of birth. Since the Soviet invasion, this situation has greatly changed, and large numbers of persons have been displaced within the country.

International migration is, of course, dominated by the movement of refugees to Pakistan and Iran. If the sum of the present population of Afghanistan plus the refugee population is taken as the total Afghan population, then approximately one out of every four persons is living outside the country. The movement of refugees, while continuing to the present, has slowed considerably since 1982. Refugees in Pakistan constitute roughly two-thirds of the total refugees.

\section{Education}

Literacy in Afghanistan, as in many developing countrles, is 10w. In 1979, less than half c $f$ the population ages 10 years and over could read and write. The percentage of males who are literate greatly exceeds the percent literate for females. The urban/rural differential in literacy is also present in Afghanistan, but is less than the observed sex differential. Although literacy levels are low, the available data for $1972-73$ and 1979 show improvement in the percent literate in each population subgroup. 


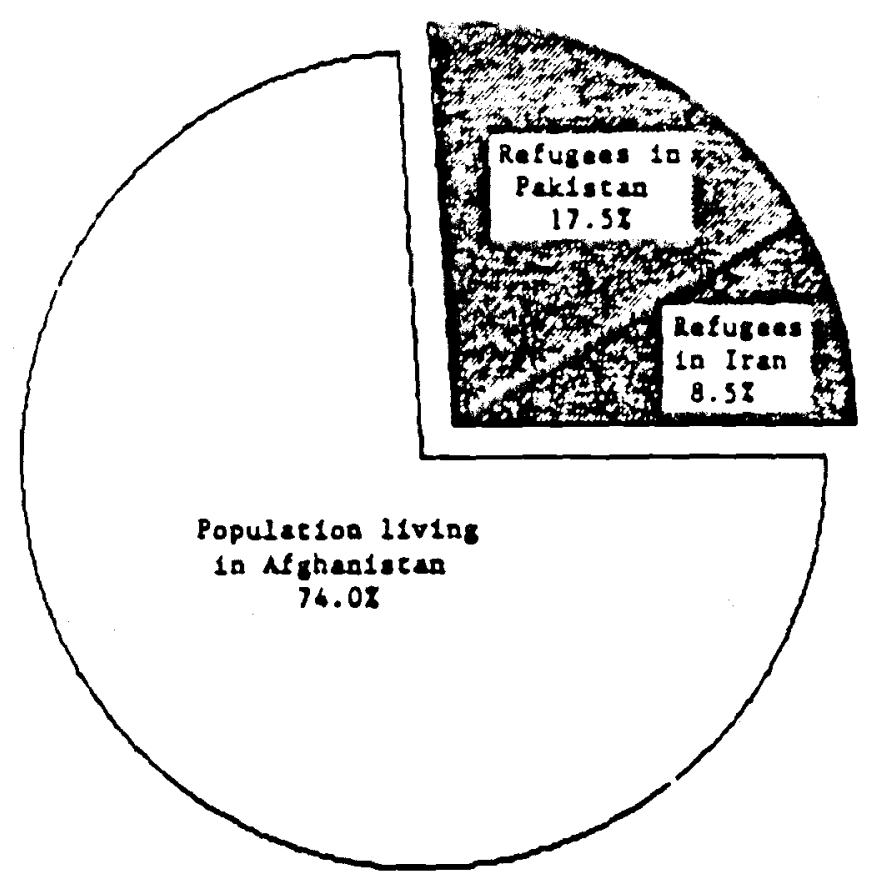

\begin{tabular}{|c|c|c|}
\hline & Afghanisten & Texas \\
\hline Total population (uillions) & 14,800 & 14,229 \\
\hline Ares (thousund squere ailes) & 250 & $\mathbf{6 7}$ \\
\hline Population demsity (pur square aile) & 60 & $\mathbf{3}$ \\
\hline Percent under age 15 yours & 4 & 2 \\
\hline Median ags & 17.6 & 28.0 \\
\hline Oild/rown ratio & 791 & 314 \\
\hline Infant wortality rate & 183 & 12 \\
\hline Percent molled in school, 5 to 24 murn 1979/1940 & 21 & 69 \\
\hline Percent woun, 1979/1980 & 15 & $\$$ \\
\hline Population of lirgest city, 1979/1980 (thousands) & 913 & 1,590 \\
\hline Persons per hospital bed, 1980-d1/1960 & 2,366 & 174 \\
\hline Persons por physician 1980-b1/1980 & 12,509 & 661 \\
\hline
\end{tabular}

Note: All data refer to 1980, except as follows. For all dates sham as year l/year 2, year I pertains to Afghanistan and your 2 to Texas. 
This report is part of a series of CIR Staff Papers issued hy the Center for International Research, 11.5. Rureau of the Census. It was prepared in the Asia, Europe, North America, and nceania Branch, under the supervision of Arjun Adlakha, Chief. Sylvia Ouick, Assistant Division Chief, and Eduardo Arriaga, Special Assistant for International Demographic Methods, provided assistance and valuable suggestions during the preparation of this report.

We are grateful to our statistical assistants vera $V$. Harris-Bourne, nonna $v$. Hart-Spriggs, Claire R. Warrick and Connie R. Woodard, for verifying the calculations and assisting in the preparation of the tables. We are also grateful to john R. Gibson for assisting in the preparation of the charts and to Rrenda S. Williams and Sheri A. Williams for typing the report.

IJsers of this report are invited to send their comments to Arjun Adlakha, Chief, Asia, Europe, North America, and Oceania Branch, Center for International Research, Rureau of the Census, Washington, D.C. 20233; telephone (301) 763-4221. 
SIIMMARY.

PRFFACE.

INTRODIICTION.

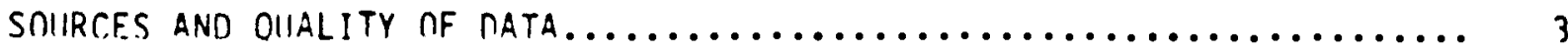

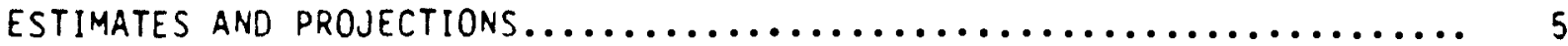

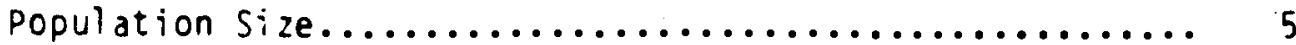

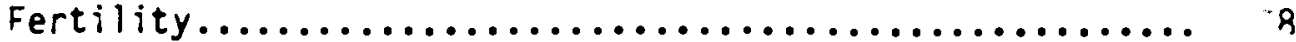

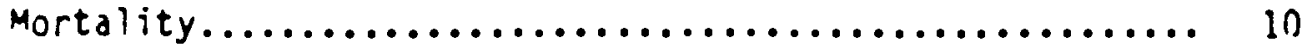

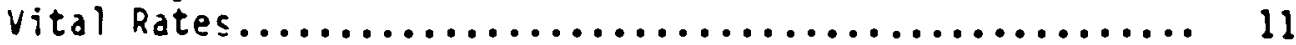

Migration.....................................

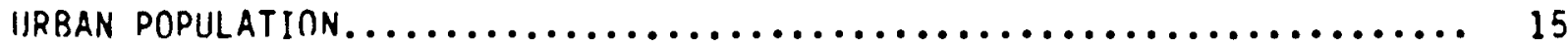

MARITAL STATUS.................................... 17

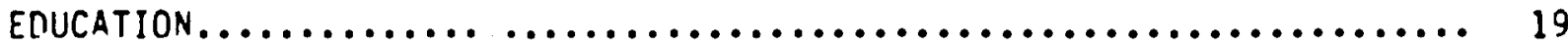

HEALTH.......................................... 23

Figure

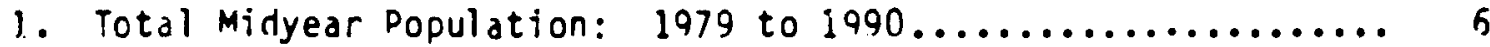

2. Total Population Projections Under Various Assumptions:

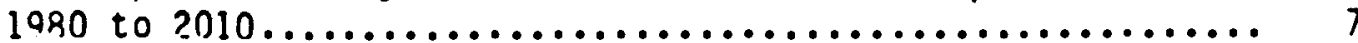

3. Projected Total Ferilitity Rates: 1980 to 2010............. 10

4. Crude Rirth, Neath, and Natural Increase Rates:

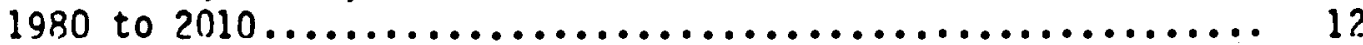

5. Percent of Women Ever Married. by Age and Urban/Rural

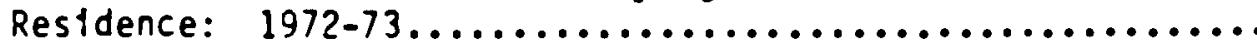

6. Percent Enrolled in School, by Sex and Urban/Rural

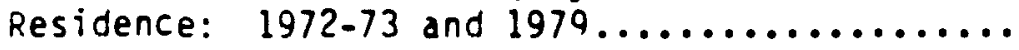

7. Dercent Literate, by Sex and Urban/Rural Residence:

$1972-73$ and 1979.

Table

1. Total Midyear Popu?ation Estimates and Perfod Growth Rates:

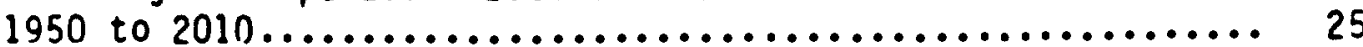

2. Smoothed Census Population, by Age and Sex: $1979 \ldots \ldots \ldots \ldots$ ?.....

3. Estimated Age-Speciftc Fertility Rates Per 1,000 Women, by

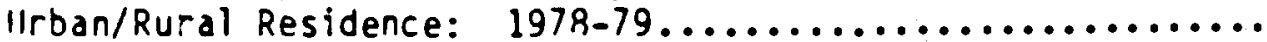

4. Estimated and Projected Total Fertility Rates: 1979 to $2010 .$.

5. Estimated and Projected Expectation of Life at Birth and

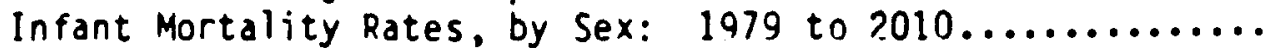
28

6. Estimater and Projected Vital Rates:

1979 to 2010 
-7. Dercentage of Native-Rorn Population Born nutside Province of Current Residence, by Age and Sex: 1972-73............. 31

8. Total and Urban Population and Percent Urban, by Province:

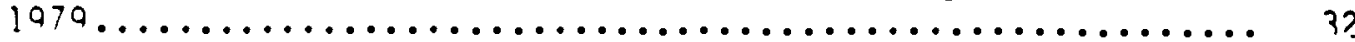

9. Dopulation of lirban Places, by size and size rilass: 1979.... 33

10. Age at Which Specified Percentage of the Population is EverMarried, by Sex and lirban/Rural Residence: 1972-73......... 34

11. Percent Married and Percent Widowed for the Population Ages 15 to 49 Years, by Sex and IIrban/Rural Residence: 1972-73.. 35

12. Total Dopulation Ages 6 to 24 Years Enrolled in School, by Age. Sex, and llrban/Rural Residence: 1977-73............. 36

13. Total population Ages 5 to 24 Years Enrolled in School, by Age, Sex, and lirban/Rural Residence: 1979................ 3i

14. Percent Literate, by Sex, Age, and IJrban/Rural Residence:

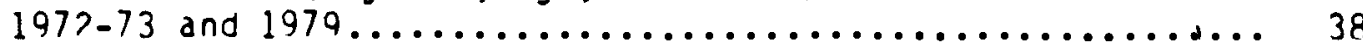

15. Selected Health Indicators: $1979-80,1980-81$, and 1981-82... 39

TECHNICAL APPENDIX

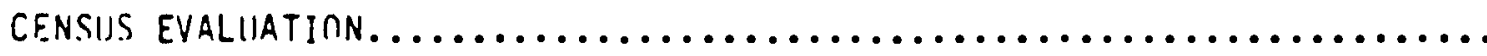

FERTILITY...................................... 42

MORTALITY...................................... 44

INTERNATIONAL MIGRATION.............................. 47

\section{APPENDIX TARLES}

A-1 . Enumerated Census Population, by Age and Sex: 1979..........

A-2. Fstimated Life Table Values for the Total Population,

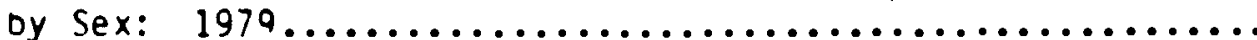

A-3. Total Population, by Marital Status, Age, and Sex:

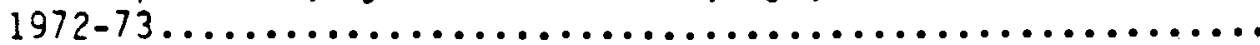

A-4. IIrban Population, by Marital Status, Age, and Sex:

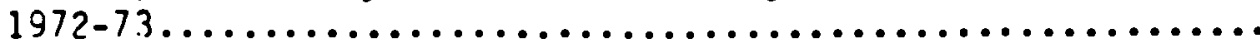

A-5. Rural Population, by Marital Status, Age, and Sex:

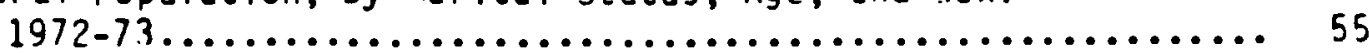

A-6. Total Literate Population, by Age and Sex: 1972-73 and 1979.. 4-7. Urban Literate Population, by Age and Sex: 1972-73 and 1979.. A-9. Rural Literate Population, by Age and Sex: 1972-73 and 1979.. A-9. Selected Population. Health, and Education Indicators, by

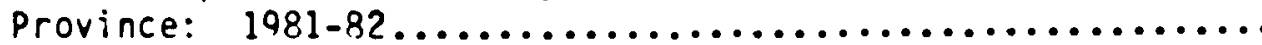

A-10. Projected Total Population Living in Afghanistan, Refugees

Living nutside Afghanistan, and Percentage of Total Afghan Population Living nutside Afghanistan: 1980 to 2010........ 


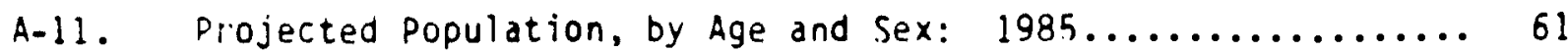

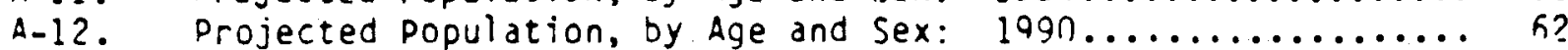

A-13. Projected Population, by Age and Sex: $1995 \ldots \ldots \ldots \ldots \ldots \ldots \ldots . . . . . .63$

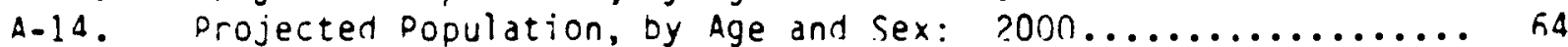

A-15. Projected Population, by Age and sex: $2005 \ldots \ldots \ldots \ldots \ldots \ldots \ldots 6 . \ldots \ldots$

A-16. Projected Population, by Age and Sex: $2010 \ldots \ldots \ldots \ldots \ldots \ldots \ldots$

MAJOR SOURCES.................................... 67 
INTROOUCTION

This study of selected demographic and soctal characteristics of the population of Afghanistan incorporates information from available sources and presents estimated and projected population parameters. Tables on population size and estimates of fertility, mortality, and migration are included. Marital status, health, urbanization, and education variables are also discussed.

Specific tables included cover arnual estimates of total population and growth rates beginning in 1950. A smoothed age and sex distribution of the 1979 census is given, plus projected age and sex distributions to 2010 .

Fertllity measures shown in the report include crude birth rates and agespecific fertility rates. Mortality is shown in terms of crude death rates, I Ife expectancies at birth, infant mortality rates, and selected iffe table functions, by age and sex. Migration measures include estimated and projected totals of the refugee population, plus lifetime internal migration estimates by age.

Selected characteristics are examined for urban and rural areas. These include trends in lifteracy and enroliment in schools and distributions of t'e population by marital status. The level of urbanization for the country and for each province Is shown. Finally, sumary statistics are presented for the total country and for provinces on varfous health indicators of the population. 

SOIIRCES AND OUALITY OF DATA

nata for the report were obtained pitimarily from the lune is to July 4,1979 population census, the 1972-73 National Demographic and Family Guidance Survey, and official statistical publications fiom the Afghanistan Cential Statistics Office. Other data incorporated in the report include reported refugees registered in camps and total refugee estimates of the United Nations High Commissioner for Refugees.

Serious difficulties arose in Afghantstan's attempt to conduct its first population census. The preliminary report states that "due to circumstancial [sic] problems on the field, which loomed up, as a result of negative factors appearing in the course of polftical and economic development of the Democratic Republic of Afghanistan created by domestic and foretgn reaction, the census enumeration could not be implemented with complete census and falled to cover the entire population of the country." As a result, only 55 to 60 percent of the settled population was estimated to have been enumerated.

During the preliminary phase of the census operation, complete coverage of the country was achteved using the household prelisting forms. From this process. information on total households and number of persons in each househol 1 was obtained. Using information collected in the prelfminary phase, the Centrai Statistics office was able, through the use of "scientffic techniques," to derive estimates for the settled population in areas which remained uncovered during the enumeration. Needless to say, the quality of the resultant statistics must be regarded as $11 \mathrm{mited}$, at best.

As a rule, special problems also arise when the attempt is made to enumerate the nomadic population of a country. Afghanistan was no exception to this 
iule. In the enumeiation, the total number of nomads obtained was believed to

De too small when viewed as a proportion of the total population. The estimated nomadic population subsequently used in the report of the preliminary census results was 2.5 million.

The enumerated age and sex distribution in a developing country generally suffers from extenstve misreporting errors. Respondents frequently do not know their age. As a result, the ages reported are often "heaped" on particular ending digits, especially 0 and 5 . Other problems include ageexaggeration and the fallure to report children that are under 1 year of age as age 0 years. The unadjusted census population, by age and sex, was not reported in the preliminary census report. Rather, the analysis of the data by the Central Statistics office produced an adjusted population by age and sex. This distribution was putilshed and, in fact, agreed with fertility and mortality estimates and expected features of the age composition. As a result, the reported distribucion, which had already been adjusted for age misieporting. as well as net coverage error, was accepted for this report. For further detalls, see the Census Evaluation Section in the Techntcal Appendix.

Throughout this report, the user of the data should recognize that while the estimates and projections shown are the best that can be prepared on the basis of avallable information, they are only tentative and new observations may well ledt to different conclusions. 
ESTIMATES ANO PRQNECTIONS

Since afghanistan has taxen only one population census, the difficulty of estimating past and future population size greatly exceeds that for countries naving a long census-taking history. The incomplete coverage of the census and the upheaval caused by the war further compound the problem of deriving population estimates in which strong confidence can be placed. Projecting an accurate demographic situation in Afghanistan is thus complicated by the dependency of the results on both base copulation estimates of uncertain. qualtty plus assumptions regarding the components of population change, most notably the future migration of the refugee population.

\section{Population size}

Afghanistan's 1987 midyear population ranked 50 th in terms of total population size. During the 30 -year period beginning after World war II until the mid1970's, Afghanistan's total population doubled. This growth was typical of many developing countries, where high fertility combined with declining mortality produced increasing population growth rates. If refugees return to Afghanistan as projected in the Center for International Research (CIR) projections, then the population is expected to double again in the next 20 years (table 1 ). Perhaps the most remarkable feature of the change in population size for Afghanistan is that the total actually declined from midyear 1979 to 1982 due to the large emigration of refugees to Pakistan and Iran (figure 1). The present population of the counter is less than that enumerated in 1979. The refugee movement more than car at the natural population fncrease reSw. j from the uxiess of births over deaths. Although persons continued leaving Afghanistan after 1982, the total net population change each year ceased 
to be negative. However, the CIR projections indicate that the total population of the country will not reach the midyear 1979 level again until 1990.

Figure 1. Total Mldyear Population:

1879 to 1980

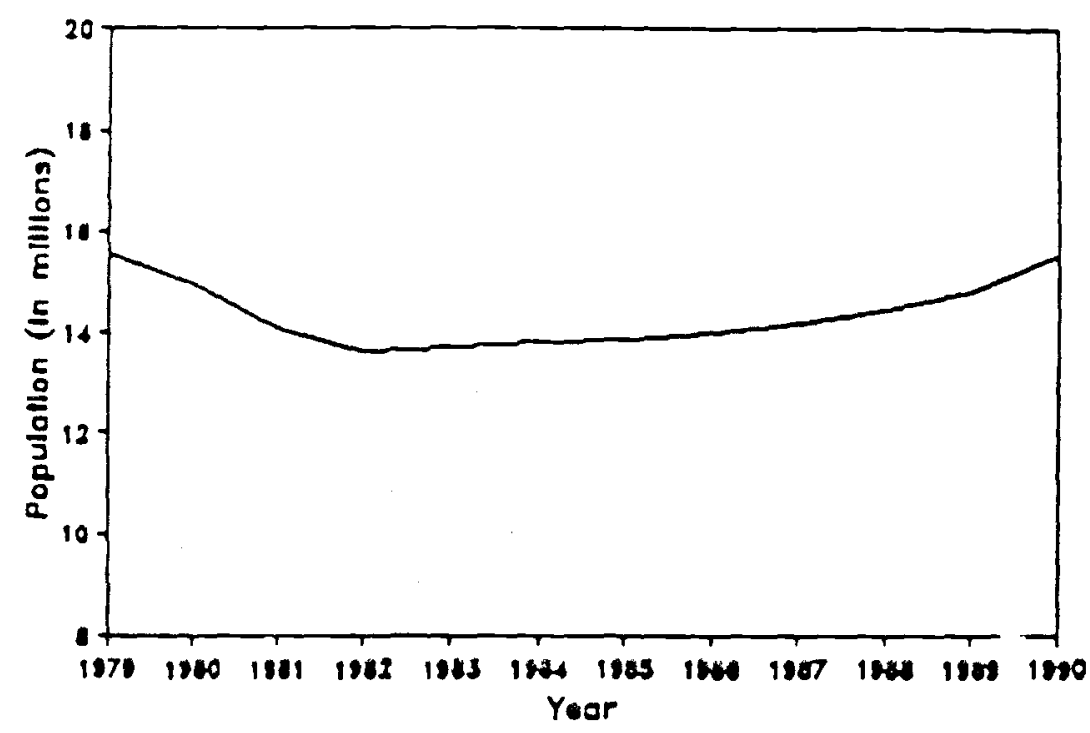

Sourca: Iable 1.

Five alternative projection assumptions were prepared for the population of Afghanistan. Each sertes employed the same prcjection assumption for mortality. The high, medium, and low fertllity projection serles assumed that Afghan refugees living in Pakistan and Iran would begln to return in 1990 . Flfteen percent of the refugee population was assumed to return in the initial year, then each year 15 percent of the remaining refugees were subsequently assumed to return to Afghanistan unt 11 2010. A fourth projection serles kept the medium fertility assumption, but altered th migration assumption so that refugees did not begin to return unt 11 199.... th the percentage returning ralsed to 20 percent each year, and with the return movement ending by 2000 . 
The fifth projection series also accepted the medium fertility series, while the migration component assumed that the refugee population does not return to Afghanistan throughout the projection period.

Figure? presents the projected total population of afghantstan under four of the five projection series. Should the refugee popularion remain in pakistan and Iran, the population is still expected to grow through the natural increase that results from the high fertility of the Afghan population. If the cu-rent situation in the country is resolved in such a way as to encourage the return of the refugee population, then Afghanistan must be prepared to absorb a rapid increase in the population. That is, the influx of such a large number of persons returning to Afghantstan will exert simflar pressure on Afghanistan as the present movement out of the country has placed on Pakistan.

Figure 2. Total Population Prolections

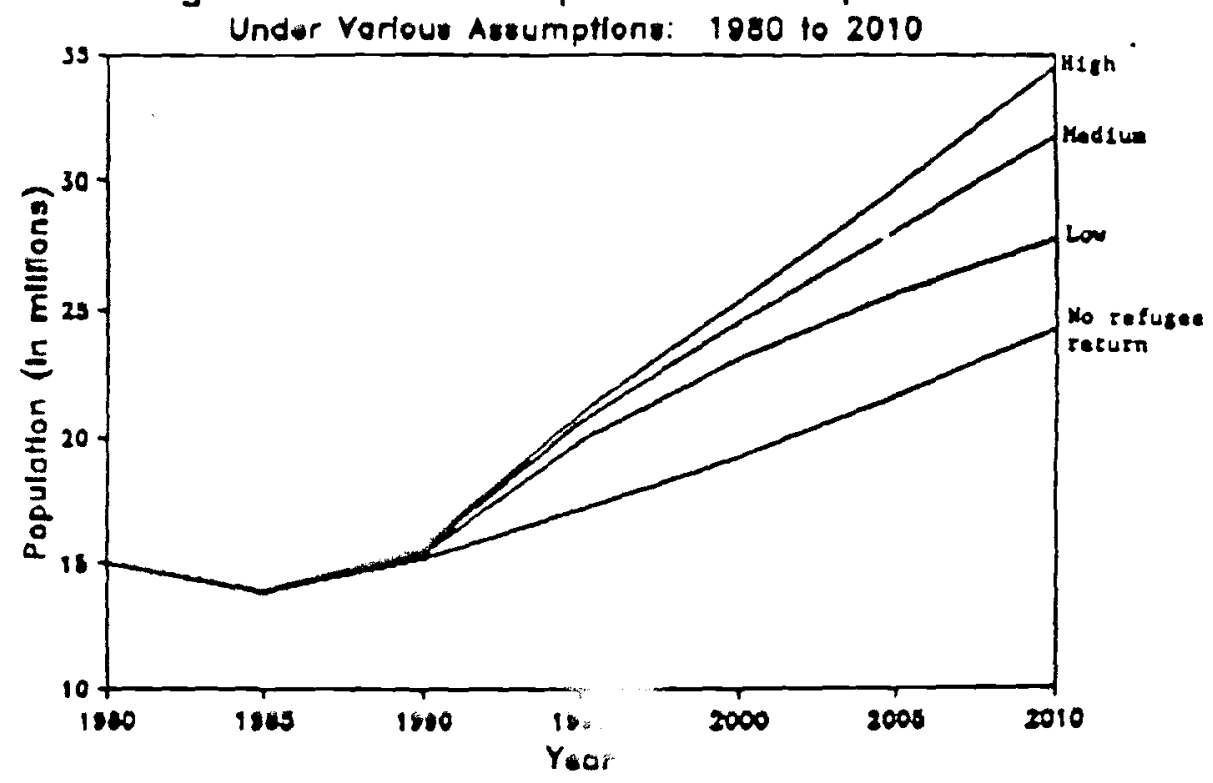

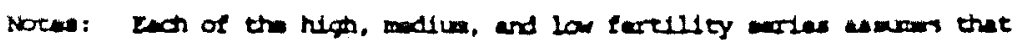

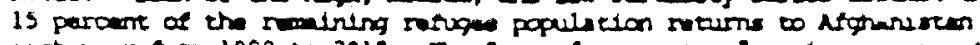

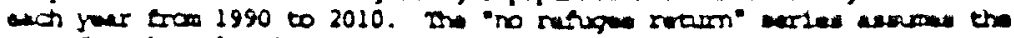

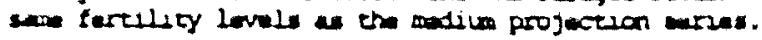

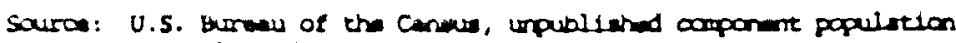
projections, selocted arian. 
While the projection of the processes of fertility and mo-tality tend to charige in a regular, relatively predictable fashion (particularly in the short term), the process of migration (especially refugee movement) is more erratic. Since refugee movement is influenced by political developments, and such political change resists prediction, the range of projected populations shown in figure 2 is highly speculative, since the outcome is largely dependent upon the assumptions made regarding the refugee population living in Pakistan and Iran.

The result of a census evaluation often leads to an adjustment of the enumerated total for either underenumeration or overenumeration. The reported total settled population of Afghanistan in the 1979 census was not adjusted by the U.S. Bureau of the census, since the reported total already reflected an unspecified level of adjustment by the Afghanistan Central Statistics office. The preliminary report states, "The total sedentary population of the country by urban/rural residence, province and MCD was subsequently estimated by adding a specific quota to the obtained results to make up for underenumeration." The resulting settled census population, by age and sex, is shown in table 2. (The inflated, unsmoothed and unadjusted census distrfbution is presented in appendix table A-1.) The totai country population estimate for the 1979 census date was 15.5 million, since the official estimate of 2.5 million nomads was also accepted.

\section{Fertility}

In many developing countries, information from a vital registration system is either of poor quality or unavailable. Data on registered births and deaths for Afghanistan are not available. Estimated fertility rates were available from the 1979 census, which collected informatiull un the number of births occuring in the 12 months prior to the census date. 
Since the fertility information on Afghanistan is limited, it is difficult

to assess past trends or to project the future course of fertility in the country. Nonetheless, do know that fertility in 1979 was high (an estimated total fertility rate of 7.1 births per woman, see table 3 ) and that the inadequacy of programs aimed at fertility reduction wlll most likely imply that the country will be characterized by relatively high fertflity in the future. Afghanistan does consider the natural growth of its population to be too high, and Afghanistan's population policy may result in lowered fertility rates, primarlly through the integration of famfly planning within maternal and child health programs.

Data from the andysis of the 1979 census indicate that there are urban and rural differences in the level of fertility (table 3 ). Urban women exhibit lower fertility rates than rural women in each age grcsp, with urban women bearing an average of 5.8 children; rural womell an average of 7.3 . These data illustrate the impact of urbanization on fertility and suggest that as Afghanistan's population becomes increasingly urban, a corresponding decline in the country's total fertflity rate may be observed.

The future path of the total fertflity rates (TFRs) in Afghanistan (table 4 and figure 3 ), as noted above, is uncertain. The widening range of rates over time as estimated by the U.S. Bureau of the Census in the high, medium, and low projection serfes reflects this uncertainty. The increasing width of the range of projected rates from the three serfes is characteristic of demographic projections, or for that matter, of any attempt to lllustrate the future. The procedures used to estimate and project the irrs for Afghanistan are discussed in the Fertility Section of the Technical Appendix. 


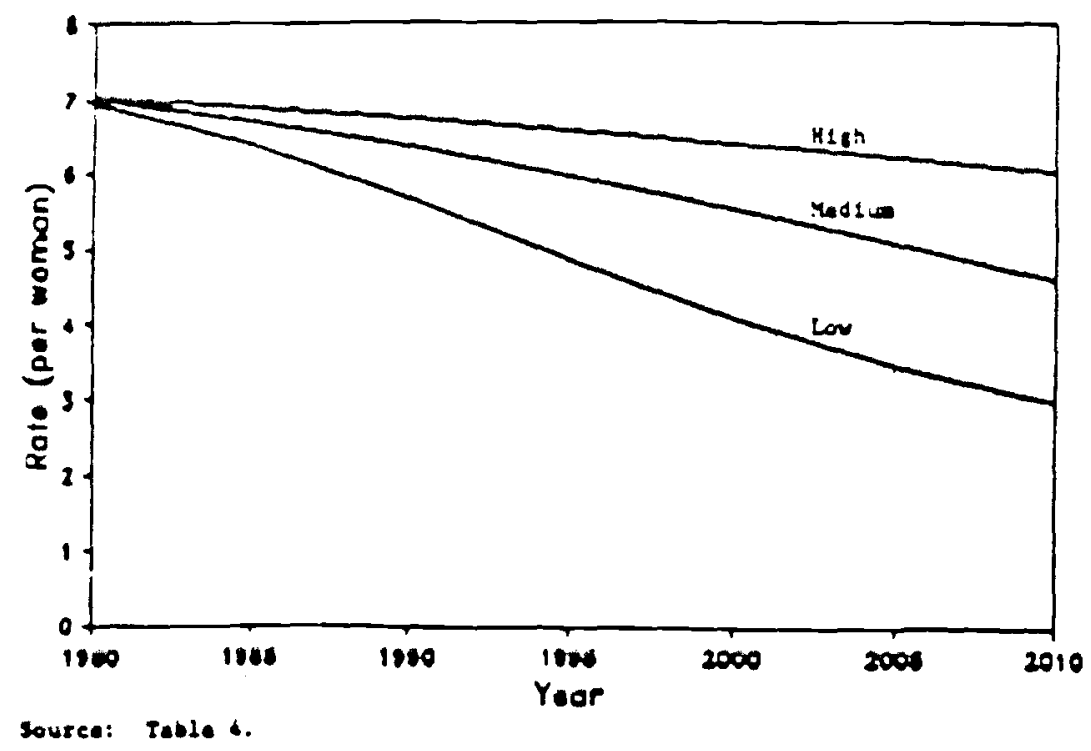

Mortality

Afghanistan has one of the lowest life expectancies at birth among all the countries of she world. It also has one of the highest infant mortality rates. These poor mortality conditions of the Afghan population existed prior to the Soviet invesion of the country.

In most developing countries, mortalfty conditions have improved through the years at varying speeds, producing general increases in 11 fe expectancy at birth. Some improvement even had occurred in Afghanistan, and would have been expected to continue in the absence of the war.

Reliable information on deaths, by age and sex, is not avaflable for Afghanistan. Data on deaths in the 12 months preceding the census date were collected in the 1979 census, adjusted by the Afghanistan Central Statistics Office, and agespecific mortality rates are presented th the preliminary census report. From these data, estimates of 11 fe expectancy at birth (table 5) and corresponding Iffe tables (appendfx table A-2) were produced for 1979. For further detalls on estfmated and projected mortalfty levels, see the Mortalfty Section of the Technical Appendix. 
In 1979, Afghanistan was one of the few countries in the world where life expectancy at birth was estimated to be higher for males than for females. This situation is not projected to change until after 2010.

While general improvement in mortality is the norm, the war in Afghanistan has, of course, had a negative impact on the mortality conditions in the country. In the absence of adequate casualty data, the projected level of life expectancy was assumed to remain unchanged fiom 1979 to 1985, thus implicitly accounting for the war's demographic impact on mortality.

\section{Vital Rates}

Although both crude birth and death rates are projected to decline in the future, there is expected to be $14 t t^{\circ}=$ change in the rate of natural increase (table 5). This indicates that while some reduction in fertility is anticipated In the coming years, a concomitant improvement in mortality will effectively negate any potential growth rate reduction through fertility decline.

The similar declines in fertility and mortality produce the flat trend in the rate of natural increase revealed in figure 4. In many developing countries, the observed mortality decline exceeded the decline in fertility, producing an increasing trend in the rate of natural increase. Such trends are responsiole for the well-known "population explosion" experienced in the developing countries of the world. In Afghanistan, mortality is not expected to decline rapidiy enough to increase the already high rate of natural increase in the future. The goverment has identified the country's natural inc: ate as too high and has introduced programs to influence this rate. 
Figure 4. Crude Birth, Death, and Natural

Incruase Rotes: 1980 to 2010

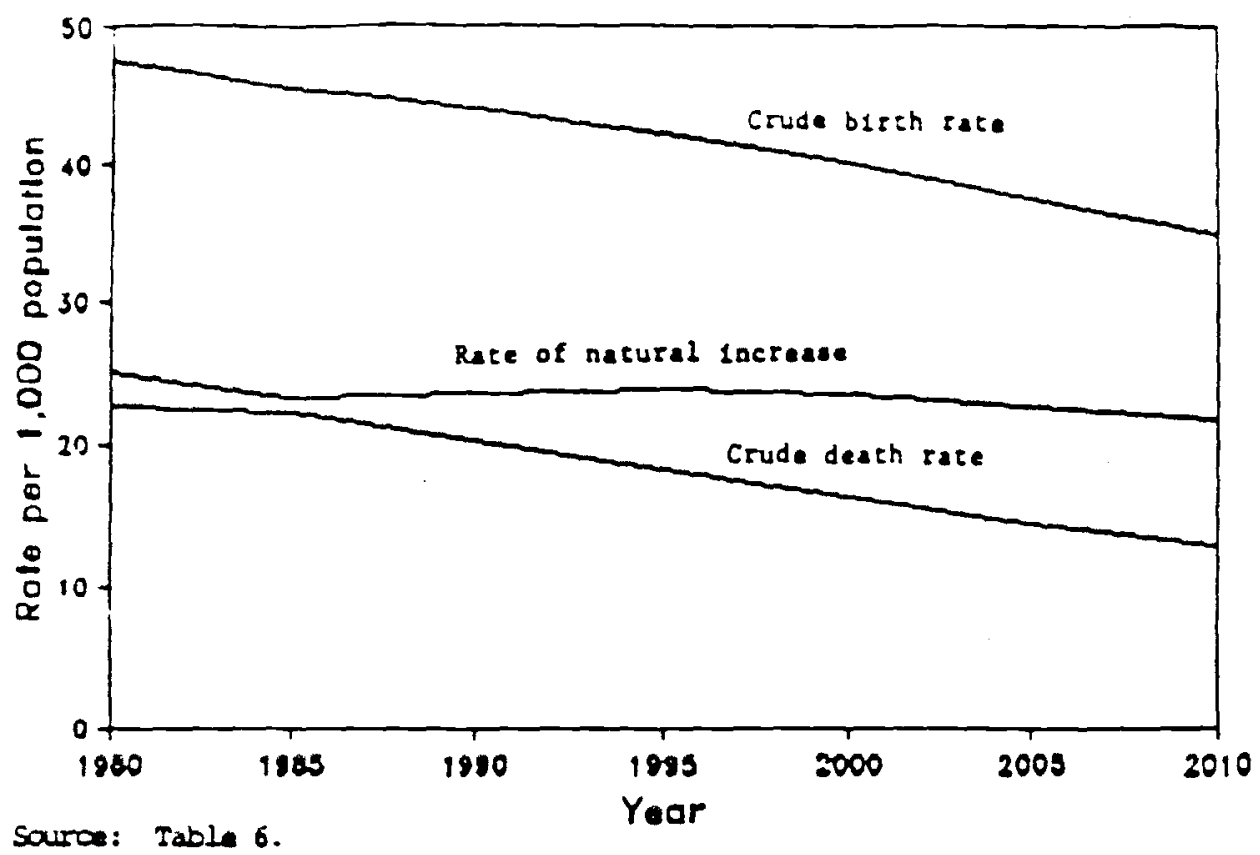

Migration

This section covers both internal and international migration of the Afghan population. Recently, both types of migration have become important aspects of the demographic situation in Afghanistan.

In the past, native-born persons in Afghanistan infrequently migrated across provincial boundaries in their lifettme (table 7). In 1972-73, 12 out of 13 native-born Afghans were estimated to be living in their province of birth. As expected, the present situation in Afghanistan, in addition to having generated large numbers of refugees (essentially, persons outside the country of their nationality and unable to return for fear of persecution), has produced a sizable number of displaced persons within the country.

Non-refugee international migration for this report is assumed to be zero. Refugee migration of Afghans to Pakistan and Iran was estimated based on reported numbers of refugees registeres in camps and reported totals of the Unfted Nations High Commissioner for Refugees. 
ronsidering the population living in Afghanistan plus the refugees in Pakistan and Iran as the total Afghan population implies that one out of four Afghans presently lives outside Afghanistan. The majority of the refugee movement had occurred by the end of 198?, with the flow of refugees continuing thereafter, but at a lower ievel.

Predicting the future of the refugee population requires that the following questions be answered. Will the outward flow of refugees increase or decrease and by how much? Will the refugees return to Afghanistan (and if so, when, at what rate of return and over what period of time)? Clearly, such questions are unanswerable by either demographers or other analysts. Notwithstanding these difficulties, the U.S. Bureau of the Census projected the total population of the refugees under selected assumptions in order to illustrate the impact of the various alternatives on the population. The effect on total population was witnessed earlier (figure 2). For further details on the estimates and projection assumptions of the refugee population, see the International Migration Section of the Technical Appendix. Detailed totals of the refugees and the population living in Afghanistan under selected projection series are shown in appendix table A-10. Projected age and sex distributions under the medium series projection (with the return of Afghan refugees beginning in 1990) are given in appendix tables A-11 through A-16. 

URBAN PODIILATION

The population of Afghanistan is predominantly rural. In 1979, 15.1 percent of the settled population of the country was reported to be living in urban areas (table 8). If the nomadic population of the country is included in the rural population, then the percent urban is reduced to 12.7 percent, implying that approximately seven out of every eight people in Afghanistar live in rural areas. Provincial variations in the percent urban for the settled population were large in 1979 , ranging from a low of 0.6 percent in Paktika Province to a high of 49.3 percent in Kabul Province.

In the 1979 census, 63 urban areas were identified. These areas met unspecified requirements as to size and urban features (although 1,000 persons is apparently the minimum acceptable size). These 63 areas represented a subset of the 86 areas recognized, by the Afghanistan Central Bureau for Leading Local Organs, as urban and deserving of municipal status. The 23 areas rejected as urban during the data processing stage of the census were considered to be "too small and lacking the required urban features" to warrant classification as urban. Of the 63 urban places, Kabul is by far the largest. Nearly half of the total urban population of the country lived in the capital city (table 0 ).

As noted in the Migration Section, the Soviet invasion has caused a considerable amount of redistribution of the population. Exactly how the geographic distribution of the population has been altered by the polftical events is indeterminable at present, and beyond the scope of the present study. 

MARITAL STATIIS

The ages at wich people marry in part influence the total number of children born. A higher median age at marriage has a dampening effect on total fertility, while a low average age at marriage tends to be associated with high fertility Quartiles showing the ages at which persons marry reveal a sex differential in the median age at marriage by urban/rural residence of between 5 and 6 years (table 10). The data from the 1972-73 Afghanistan National Demographic and Family Guidance Survey also demonstrate the earlier age at marriage of both males and females in rural areas compared to persons living in urban areas. For example, while half of all urban females are estimated to be married by age 18.7 years, in rural areas the age by which half the female population has married is 16.4 years.

The urban/rural differentials in the age at wich various percentages of the population is ever-married contribute to explaining the differences in total fertility rates by type of residence. However, while rural women may marry earlier than urban women, providing rural women with more years of exposure to childbearing than urban women, urban/rural differences in the percent evermarried disappear by age group 30 to 34 years (figure 5 ). This demonstrates the universality of marriage in Afghanistan.

While the percentage of women ever-married generally increases with age, the percentage of the female population in Afghanistan that is currently married begins declining after age 30-34 years in urban areas, and 25-29 years in rural areas (table 11). This decline reflects the increasing percentage of the 
Figure 5. Percent of Women Ever Married,

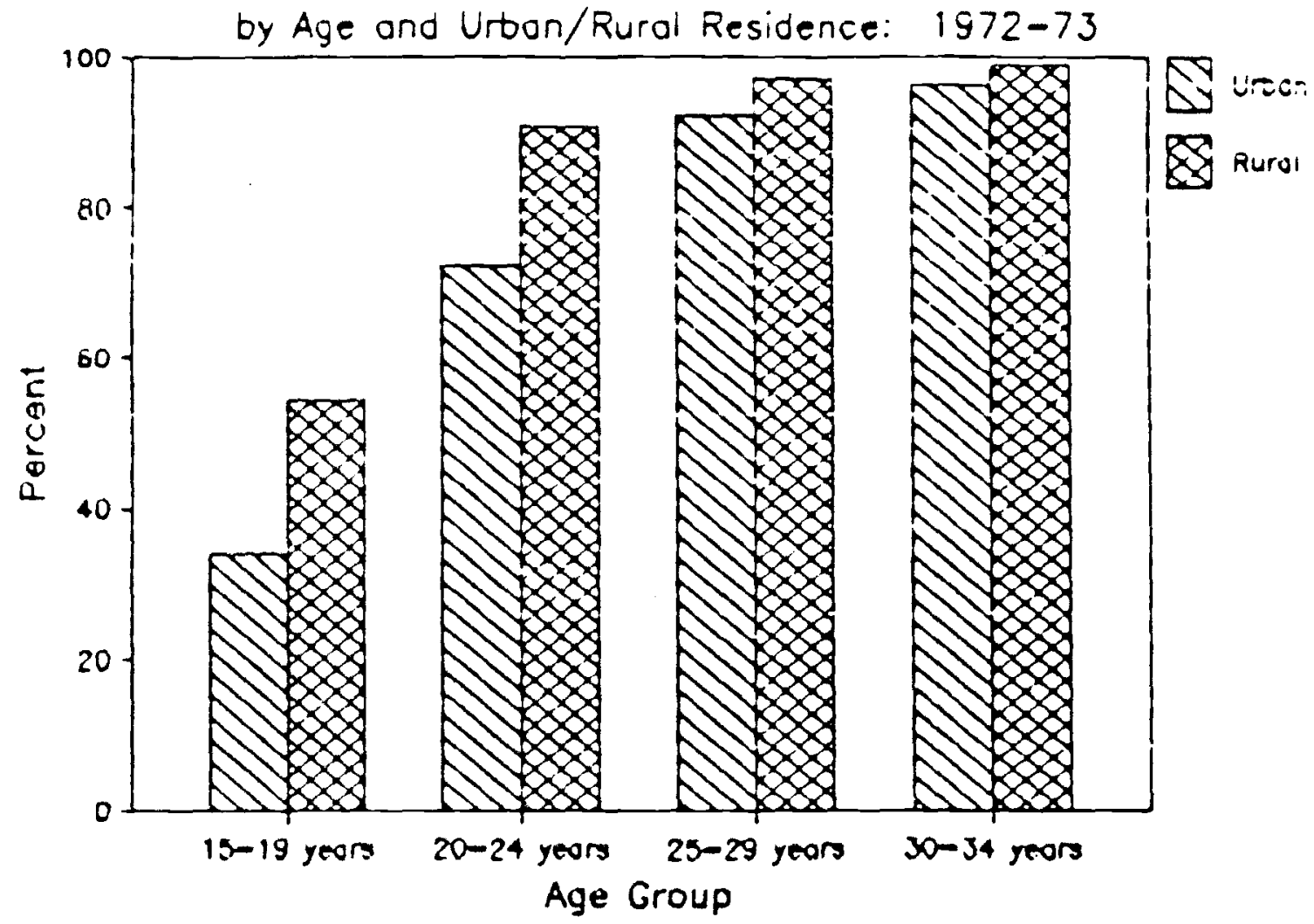

Source: Appendix tables $A-4$ and $A-5$.

population widowed with increasing age. The 1972-73 marftal status data show slight differences in the percent widowed between urban and rural areas, indicating slightly higher mortality for the rural population. The male-fenale differences in the percent widowed, rather than suggesting substantial sex diffe entials in mortalfty, reflect the greater likelihood for males to remarry than for females. (For detailed marital status data by age and urban/rural residence in 1972-73, see appendix tables $A-3$ through $A-5)$. 


\section{EDUCATION}

Improvements in the educational attainment of a population, like increases in uroanization and age at first marriage, are associated with declines in fertility rates. Available data from the 1972-73 National Demographic and Family Guidance Survey and the 1979 population census reveal some increases in the percentage of the total school-age population enrolled in school during the period (tables 12 and 13). Since 1972-73 information covered the population ages 6 to 24 years, while the 1979 data included persons ages 5 to 24 years, figure 6 compares the urban/rural and male/female differences in the percentage of the population enrolled in school for persons ages 10 to 24 years.

Figure 6. Percent Enrolled in School, by Sex

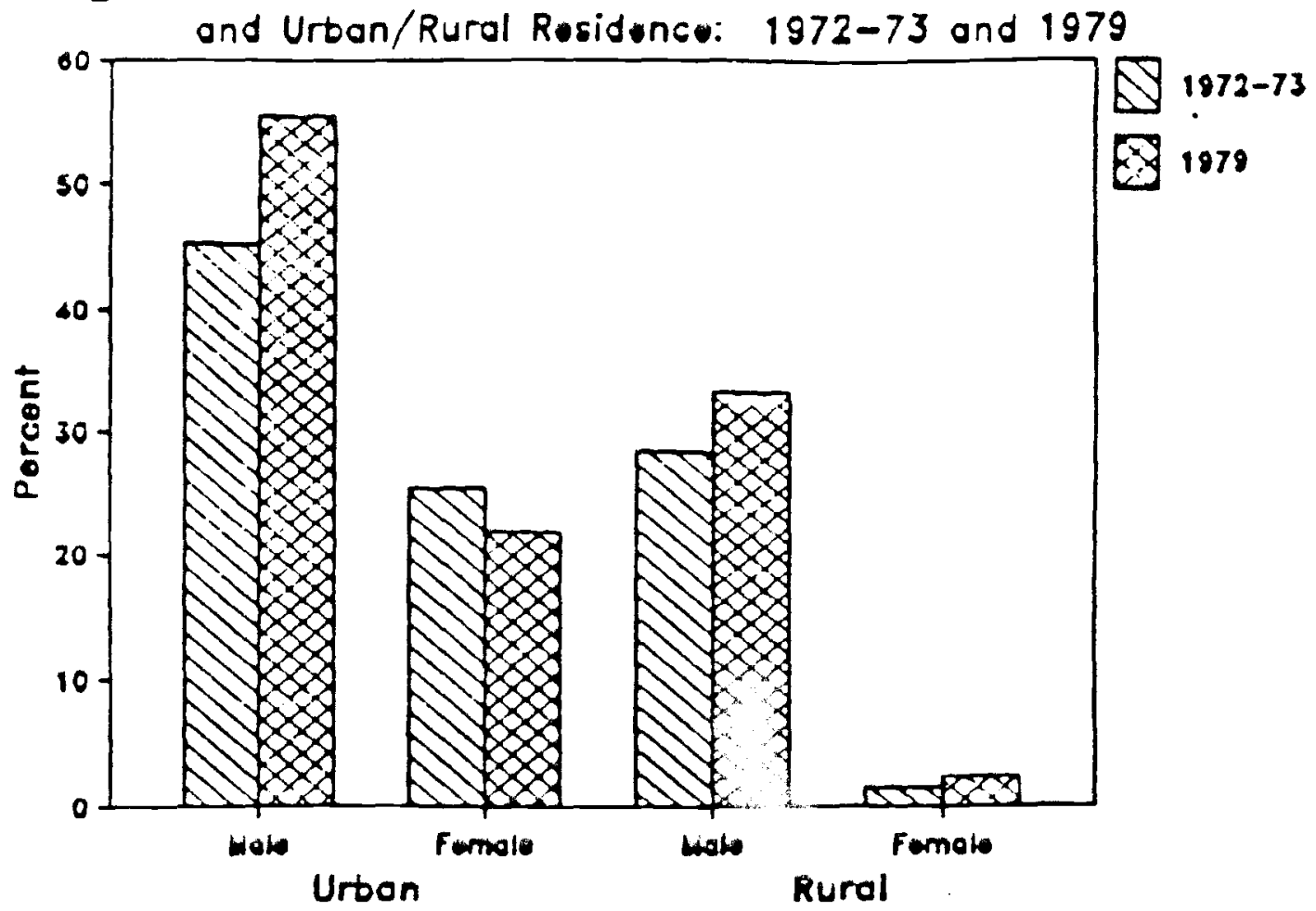

Hotei Data roler to the population ege 10 to 24 years.

Source: ruble 12 and 13. 
Note that the observed sex differentials, as well as the urban and rural differences, are quite large. Apparently, gender is a more important influence on enrollment than type of residence, since a higher proportion of rural males are enrolled than urban females. Curiously, the percentage of urban females enrolled is shown to have declined between 1972-73 and 1979 .

Changes in the percentage of the Afghan population that is literate from 1972-73 to 1979 (table 14) reveal trends simflar to those shown by the enrollment data. While overall literacy levels had improved, by 1979 slightly more than one out of five Afghan persons ages 10 years and over could read and write. In contrast to the enrollment data, urban female literacy exhfofted an improvement over the period (figure 7). While each sex and restdence type experienced some improvement in literacy, the improvement of males clearly surpassed that of females. In 1979, 96 out of every lco rural females were flliterate.

Figure 7. Percent Literate, by Sex.

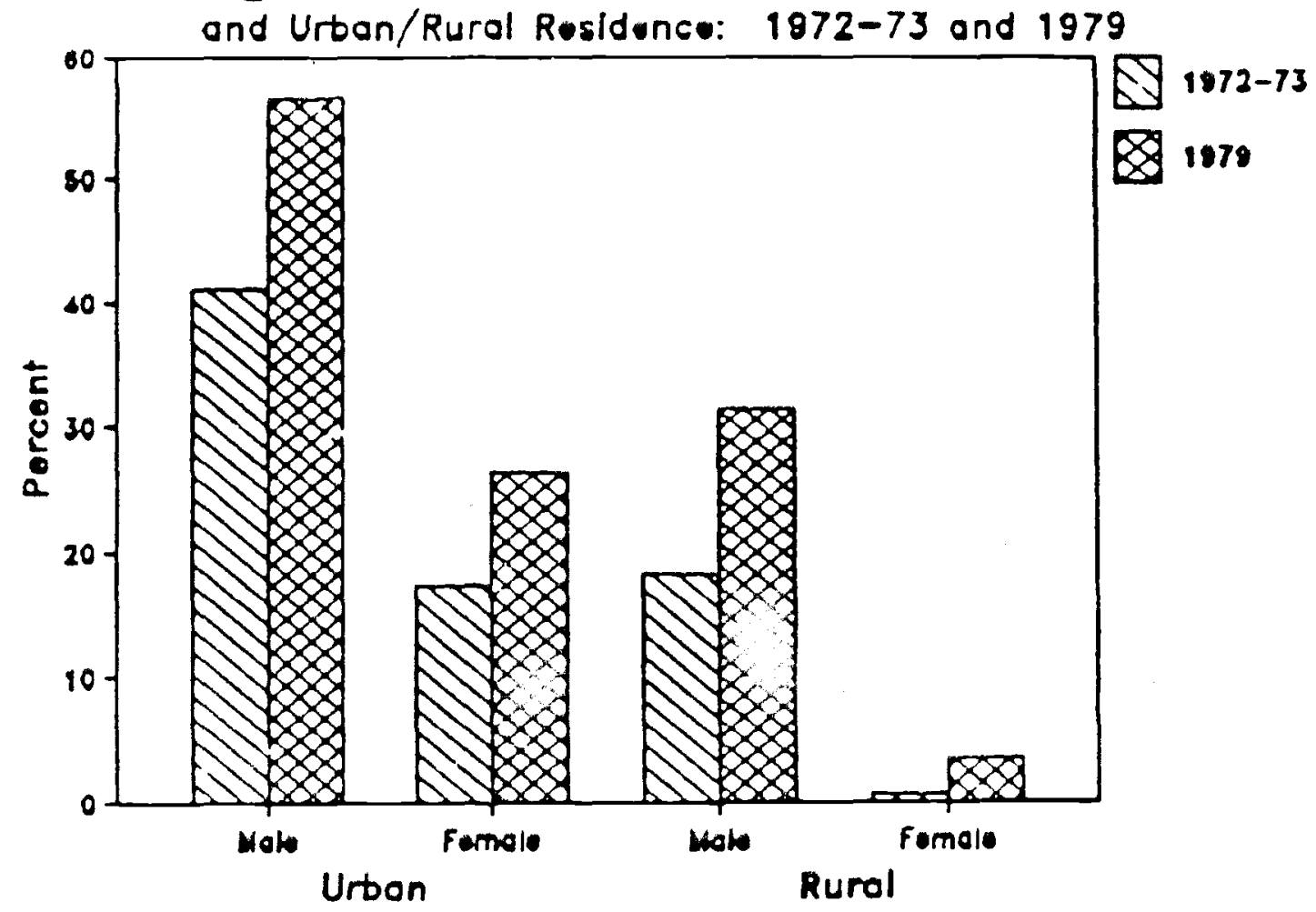

Note: Data refere to tha population geo 10 yours and over.

Source: Table 14. 
The percentage of the Afghan population that is literate generally decreases witn increasing age. Thus, while three-fourths of urban males ages 10 to 14 years were literate in 1979 , lesc than one-half of urban males ages 35 to 44 years and less than one-half of urban males ages 55 to 64 years could read and write. (See appendix tables A-6 through A-8 for detailed literacy data by age and urban/rural residence.)

Although education data for the recent years are not available on the percent enrolled or literate, the present government has instituted a large adult literacy campaign and programs exist to export Afghan students for study in the Soviet Union. Reliable information on the measurable progress made by these efforts is unavailable, although reports indicate that success has been quite limited. 

HEALTH

The health situation in Afghanistan, as should have been clearly inferred from the mortality discussion earlier, is poor. Official statistics available from 1979-80 to 1981-82 on selected health indicators shed some light on the progress of the government toward providing adequate health facilities for the population (tahle 15).

nuring the period 1979 to 1982 the number of hospital beds increased by 11 to 12 percent per year. Also, the number of persons per hospital bed declined during this period. These trends suggest improvenent in the availability of health facilities to the population. Note that the decline in persons per hospital bed would have occurred even if there had been no population loss due to refugee movement. Still, comparing the number of persons per hospital bed in 1981-82 $(2,016)$ with the corresponding number of persons (185) for a place of similar population size and density (Texas) emphasizes the low level of provision of health care. Evell comparing this statistic for Afghanistan with the 1976 data of another developing country of similar size and density (Iraq) shows that Afghanistan has greatly defictent health care coverage. (Iraq had an estimated 492 persons per hospital bed in 1976). For selected 1981-82 health indicators, by province, based on official data, as well as provincial population and education indicators, see appendix table A-Q.

Current health data are not available, but a recent report (U.S. Department of State, 1986) states, "The length of the conflict and the disruption of Afghanistan's rudimentary health infrastructure have contributed to an apparent increase in the incidence of disease. Most doctors have fled." The official data on the number of physicians through 1982 do not support the statement regarding doctors, 
although the situzzion certainly may have changed since laz? (or the official ca:a may be incorrectl. In any case, the major point to recognize from the available health indicator information is that health care services before the Soviet invasion were highly inadequata. Subsequent developments in the country have undoubtedly exacerbated the already poor health situation. 
Table 1. Trital Midyear Population Estimates and Period Growth Rates: 1351) to En1? iFopulation ir thousarids, griwin rate ar, fercerit,

\begin{tabular}{|c|c|c|c|c|c|c|}
\hline \multirow[b]{2}{*}{ Year. } & \multicolumn{2}{|r|}{$\begin{array}{l}\text { Average } \\
\text { annisal }\end{array}$} & & \multicolumn{3}{|c|}{$\begin{array}{r}\text { Average } \\
\text { aririll }+1\end{array}$} \\
\hline & Fopulation & growth rate & Year & Populaticin & growth & rate \\
\hline Est dinates & & & Project & & & \\
\hline 1350 & 8,150 & 1.74 & 1381 & 14,085 & : & -3.20 \\
\hline 1355 & 8,891 & 2. (1) & 1982 & 13,642 & & $\therefore 45$ \\
\hline $13 E 0$ & $3,8=9$ & 2.. .5 & 1383 & 13,703 & & $0.8 \overline{3}$ \\
\hline $13 E 5$ & 10,998 & 2.45 & 1984 & 13,817 & & 0.49 \\
\hline 1370 & 12,431 & 2.57 & 1985 & $13,8 B 6$ & ${ }^{-}$ & $0 . \dot{E} 8$ \\
\hline 1975 & 14,132 & 2. 58 & 1986 & 13,781 & - & 1.44 \\
\hline 1976 & 14,501 & 2.58 & 1387 & 14,184 & & $\Xi .07$ \\
\hline 1977 & 14,880 & 2.58 & 1988 & 14,481 & & 2.35 \\
\hline 1378 & $15,=63$ & 1.86 & 1389 & 14,825 & & 5.04 \\
\hline Projections & & & $\begin{array}{l}1990 \\
1995 \\
2000\end{array}$ & $\begin{array}{l}15,592 \\
20,561 \\
24,501\end{array}$ & & $\begin{array}{l}5.53 \\
3.51 \\
2.76\end{array}$ \\
\hline 1373 & 15,556 & -3.74 & 2005 & 28,123 & & 2.41 \\
\hline 1380 & 14,985 & -6.19 & 2010 & 31,736 & & $(x)$ \\
\hline
\end{tabular}

$x$ - Not applicatle.

Source: U.S. Eureau of the Cerisus, uripublished componerit population projections, medium series. 
Taule ¿. Smopthed Censis Population, by Age and Sex: 1373

ifipisition in thousarids arid may rot ad to tetals dise to rounding?

\begin{tabular}{|c|c|c|c|}
\hline fge & Enth sexes & Male & Fenale \\
\hline All ages & $1 \overline{3}, 051$ & 6,710 & $\therefore, 342$ \\
\hline 0 to 4 years & 2,337 & 1,195 & $1,14 \bar{c}$ \\
\hline 5 to 3 years & 1,876 & 351 & $9: 5$ \\
\hline 10 to 14 years & 1,604 & 819 & 785 \\
\hline 15 to 13 years & 1,373 & 702 & E7i \\
\hline$\Xi 0$ to 24 years & $1,1 \in 3$ & 597 & $-56 \epsilon$ \\
\hline ¿s to $\Xi \exists$ years & 978 & 500 & $\cdots 478$ \\
\hline 30 to 34 years & 819 & 420 & 393 \\
\hline 35 to 33 years & 681 & 350 & 3311 \\
\hline $4 i^{\circ}$ to 44 years & 560 & 291 & $\therefore 70$ \\
\hline 45 to 49 years & 458 & 237 & $\Xi \geq 1$ \\
\hline 50 to 54 years & 370 & $19 \hat{e}$ & 178 \\
\hline 55 to 53 years & 231 & 153 & 133 \\
\hline 60 to 04 years & 218 & 116 & 103 \\
\hline ES to 67 years & 151 & 82 & $7 i$ \\
\hline 70 te 74 years & 98 & 57 & 41 \\
\hline 75 to 79 years & 48 & 31 & 18 \\
\hline years and over & $\Xi E$ & 17 & 9 \\
\hline
\end{tabular}

Noites: Figures exclude nomads, estimated at 2.5 million for the census date. Due to political inrest within the country, not nore than 55 to 60 percent of the settled population could be enumerated. Estinlates for the settled population in areas which were not covered by the enumeration were based on information obtained during the preliminary phases of mapping, cartography, and household prelisting. The subsequerit results were officially adjusted by ari application of "certain corrective devices" and "scient ific techniques."

Source: Afgrianistari Ceritral 5tatistacs Dffice, 1381, Firelimiriary Results of the First Afghan Population Censis, Publication NO. 1 , Demegraphic Statistics, Kabul, arinek tables 5, 5-1, arid 5-2. 
Taole 3. Estinated Age-Specific Fertility Rates

Fer 1, 000 Womer, by UrbariRural Residence: $1378-73$

\begin{tabular}{|c|c|c|c|}
\hline Age & Tiatal & Undan & Risral \\
\hline $15 t: 13$ yes.s & $1 \geq 5$ & 118 & \\
\hline$\because t: \Xi 4$ years & $\Xi 88$ & 255 & \\
\hline$\Xi 5$ t $\Xi 9$ years & 316 & ¿E7 & \\
\hline jo to 34 years & 268 & 235 & 273 \\
\hline 35 to 33 years & $\Xi 17$ & 171 & 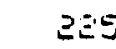 \\
\hline 40 to 44 years & $1=0$ & 75 & 140 \\
\hline 45 to 49 years & 72 & 41) & \\
\hline $\begin{array}{l}\text { Total fertility rate } \\
\text { (per woman) }\end{array}$ & 7.08 & 5.80 & 7.31 \\
\hline
\end{tabular}

Notes: Data refer to the settled pipulation only. Urban initially referred to the 86 areas recogriszed by the Ceritral Eureau for Leading Local Orgaris as urban and deserving if nunicipal status, but during processing of the cerisus resilts 23 of these areas were determined to be "too small and lacking the required urban features" to warrant classification as urban. Hence, urban was cperationally defined as 63 areas recognized as such by the Central Eureals for Leading Local Organs. These areas met unspecified requiremerits as to size and urbari features.

Source: Afgnaristan Central Statistics Office, 1981, Preliminary Results of the First Afghan Population Census, Fidolication No. 1, Demographic Statistics, Kabul, annex table 4 . 
Taole 4. Estimated arid Frojected Tata:

Fertility Rates: 1979 to 2010

\begin{tabular}{|c|c|c|c|}
\hline \multirow[b]{2}{*}{ Year } & \multicolumn{3}{|c|}{$\begin{array}{l}\text { Tetal fertildty rate } \\
\text { (per withari) }\end{array}$} \\
\hline & Low & Medaum & $\mathrm{H}$ Ign \\
\hline \multicolumn{4}{|c|}{ Estimate } \\
\hline 1973 & & 7.018 & \\
\hline \multicolumn{4}{|c|}{ Frojections } \\
\hline 1380 & 6.97 & $7.0 \bar{~}$ & 7.05 \\
\hline 1381 & 6.86 & 6.97 & 7.03 \\
\hline $198 \Xi$ & 6.76 & 6.91 & 7.00 \\
\hline 1383 & 6.65 & 6.85 & 6.97 \\
\hline 1984 & 6.54 & 6.80 & 6.95 \\
\hline 1985 & 6.43 & 6.74 & 6.92 \\
\hline 1986 & 6.29 & $6 . E 7$ & 6.89 \\
\hline 1387 & 6.14 & 6.60 & 6.86 \\
\hline 1988 & 6.00 & 6.54 & E. 84 \\
\hline 1383 & 5.85 & 6.47 & 6.81 \\
\hline 1330 & 5.71 & 6.40 & 6.78 \\
\hline 1731 & 5.55 & 6.32 & 6.75 \\
\hline 1392 & 5. 39 & 6.24 & $6.7 \ddot{c}$ \\
\hline 1393 & 5.23 & 6.17 & 6.68 \\
\hline 1394 & 5.07 & 6.09 & 6.65 \\
\hline 1935 & 4.91 & 6.01 & 6.62 \\
\hline 1396 & 4.75 & 5.92 & 6.59 \\
\hline 1937 & 4.60 & 5.84 & 6.55 \\
\hline 1398 & 4.44 & 5.75 & 6.52 \\
\hline 1993 & 4.29 & 5.67 & 6.48 \\
\hline 2000 & 4.13 & 5.58 & 6.45 \\
\hline 2005 & 3.48 & 5.12 & 6.26 \\
\hline 2010 & 3.01 & 4.66 & 6.06 \\
\hline
\end{tabular}

Source: U.S. Bureau of the Census, unpublished component population prijections, low, medium, and high series. 
Table 5. Estlmated and Projected Expectation of Life at Eirth and Irifarit Mertality Rates, by Sex: 1379 to Enlo

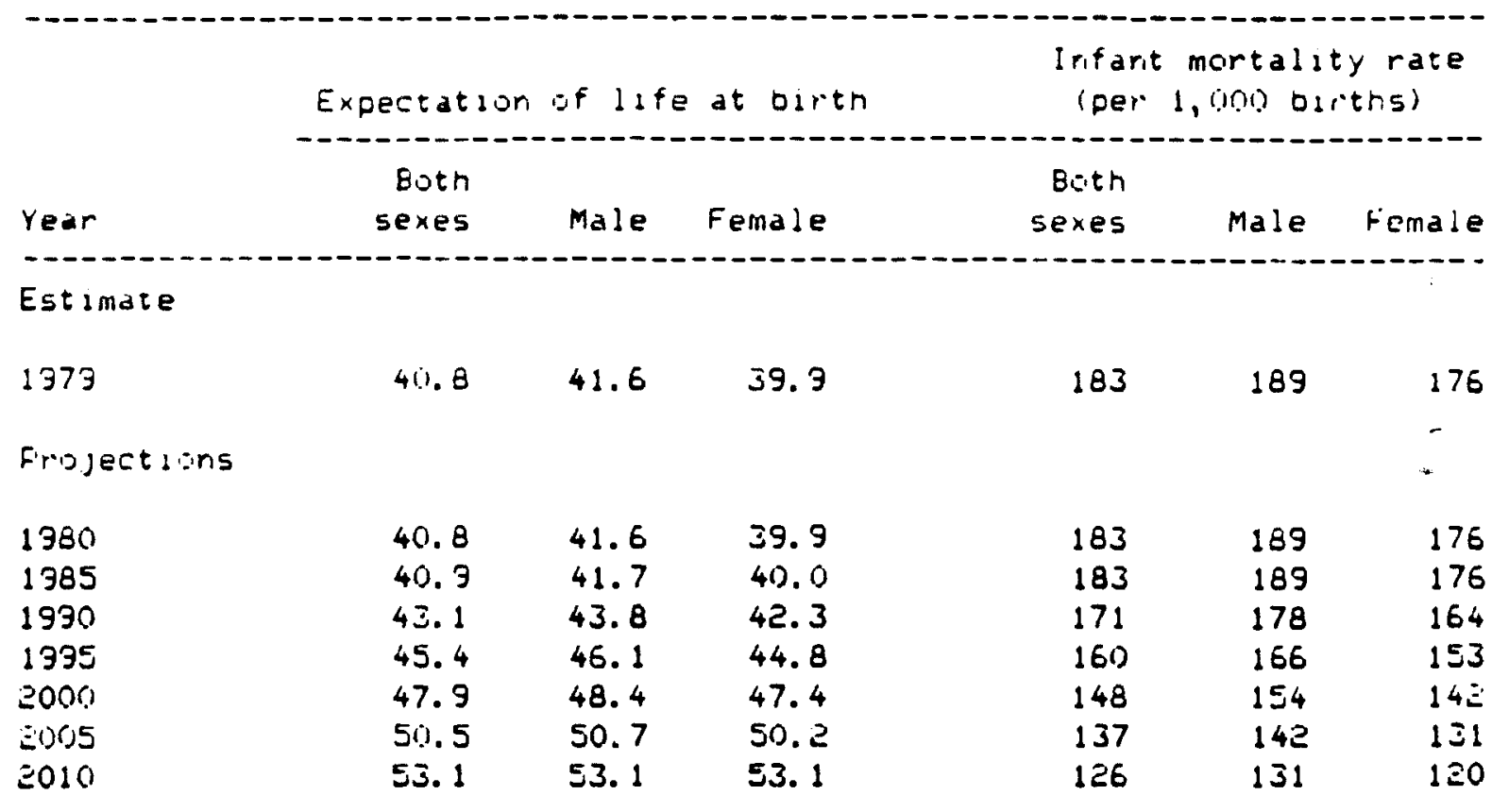

Source: Estimated and projected at the U.S. Bureau of the Census based on estimated life tables derived from adjusted age-specific death rates for 1979, assumed constant mortality to 1985, and logistic iriterpolation between the 1385 level of life expectancy and assumed levels for 2000 (for inales) arid 2010 (for females). For further discussion, see the Mortality section of the Technical Appendix. 
Table E. Estiliated and Frojected Vital Rates: 1373 to 2010

\begin{tabular}{|c|c|c|c|c|c|c|c|c|c|}
\hline \multirow[b]{2}{*}{$Y=$ iो } & \multicolumn{3}{|c|}{$\begin{array}{l}\text { Cride birth rate } \\
\text { (fer i, goo } \\
\text { population) }\end{array}$} & \multicolumn{3}{|c|}{$\begin{array}{c}\text { Cride death rate } \\
\text { (per } 1,100 \\
\text { population) }\end{array}$} & \multicolumn{3}{|c|}{$\begin{array}{l}\text { Rate } \therefore f \\
\text { ratural increase } \\
\text { (percent) }\end{array}$} \\
\hline & $\therefore w$ & Mectsin & Hign & Low & Medalu & $H+g h$ & WW WW & Meddisin & High \\
\hline \multicolumn{10}{|c|}{$E \equiv t$ unate } \\
\hline 1973 & & 48.1 & & & $\Xi .5$ & & & Z.E & \\
\hline \multicolumn{10}{|c|}{ Firejectajus } \\
\hline 1380 & 47.3 & 47.6 & 47.8 & 22.6 & 23.7 & 22.7 & 2.5 & 2.5 & $\Xi .5$ \\
\hline 1381 & $4 E .5$ & 47.1 & 47.5 & 22.6 & 22.7 & $\Xi 2.8$ & 3.4 & 2.4 & I. 5 \\
\hline $198 \Xi$ & 45.7 & 46.6 & 47.2 & 2ב. 6 & 22.7 & 22. 8 & 2. 3 & $\Xi .4$ & $\Xi .4$ \\
\hline $128 \overline{3}$ & 45.1 & 46.3 & 47.0 & $\Xi \Xi 3$ & $\Xi .6$ & 로. 7 & 2.3 & 2.4 & $\dot{\Delta} .4$ \\
\hline 1984 & 44.5 & 46.0 & $4 E .9$ & วЕ.こ & Е.2. 5 & 23.6 & 2.2 & 2. 4 & 2.4 \\
\hline 1385 & 43.9 & 45.6 & 46.7 & 2.. 0 & 2こ. 4 & 2.2. 6 & 2.2 & $\Xi .3$ & 2.4 \\
\hline 1990 & $40 . \overline{3}$ & 44.0 & 46.2 & 19.8 & 20.4 & 20.8 & e. 1 & E. 4 & 2.5 \\
\hline 1.395 & 36.5 & 42.4 & 45.7 & 17.5 & 18.4 & 18.3 & 1.3 & $\Xi .4$ & 2. 7 \\
\hline$=000$ & $\exists \Xi . \epsilon$ & 40.3 & 44.8 & 15.4 & 16.5 & 17.1 & 1.7 & 3.4 & 2.8 \\
\hline Enos & 29.7 & 37.6 & 43.5 & 13.7 & 14.7 & 15.4 & 1.5 & 3 & 2.8 \\
\hline 5010 & 25. 8 & 35.0 & 42.3 & 12.3 & 13.0 & 13.7 & 1.4 & ह่. 2 & 2. 9 \\
\hline
\end{tabular}

Source: U.S. Bureau of the Census, unpublished component population projectians, low, inedium, arid high series. 
Taule 7. Fercentage of Native-Born Population Born Outside Previrice of Currerit Residerice, by Rge are Sex: 1372-7:

\begin{tabular}{|c|c|c|c|}
\hline nige & $\begin{array}{l}\text { Euth } \\
\text { sexes }\end{array}$ & Maie & Fenale \\
\hline$r a:$, all & 77 & 3. & $7 . \Sigma$ \\
\hline$\therefore$ to 3 years & 4.0 & 4.1 & 4.0 \\
\hline 10 to 14 years & 6.0 & 6.4 & 5.6 \\
\hline 15 to 13 years & 8.0 & 8.2 & 7.8 \\
\hline$\Xi 0$ to $\Xi 4$ years & 3.6 & Э. 3 & 3.2 \\
\hline Es to $\equiv 3$ years & 10.0 & 10.7 & 3.3 \\
\hline 30 to 34 years & 10.0 & 10.1 & 10.0 \\
\hline 35 to 39 years & 11.4 & 12.0 & 10.7 \\
\hline 40 to 44 years & 11.7 & 12.6 & $10.5^{-}$ \\
\hline 45 to 49 years & 11.5 & $1 \Xi .7$ & 3.9 \\
\hline 5i) to $\$ 4$ years & 11.8 & 13.3 & 10.1 \\
\hline 55 to 59 years & 10.4 & 10.4 & 10.3 \\
\hline Ei) to 64 years & 11.9 & 12.7 & 10.8 \\
\hline 65 to $E 9$ years & 10.8 & 10.2 & 11.7 \\
\hline 70 to 74 years & 12.4 & 13.1 & 11.3 \\
\hline 75 years arid over & 17.1 & 15.2 & 20.9 \\
\hline Unknown age & 25.1 & 27.1 & 21.0 \\
\hline
\end{tabular}

Note: Data refer to the settled population only.

Source: Afgharistan Central Statistics Office, 1975, National Demigraphic arid Family Guidance Survey of the Settled Population af Afgnaristan, Vol. 3, Tables, Kabul, tables 13.1.1, 13.1.2, arid 13.1. 3. 
Table 8. Tiatal and Urban Piopulatiori and Percent Urtan, Dy Frevirice: 1979

\begin{tabular}{|c|c|c|c|}
\hline \multirow[b]{2}{*}{ Frodice } & \multicolumn{2}{|c|}{ Fopulatzon } & \multirow{2}{*}{$\begin{array}{l}\text { Fercer.t } \\
\text { Uroar. }\end{array}$} \\
\hline & $T$ Tal & Uroari & \\
\hline Total, all areas & $13,051,358$ & $1,376,758$ & 15.1 \\
\hline Badakhsharı & 497,758 & 10,142 & $\Xi .0$ \\
\hline Badghes & 233,613 & 5,340 & 2.3 \\
\hline Eaghlar. & 493,882 & $75,1=0$ & 1. .2 \\
\hline Balkn & $5 \in 3,255$ & 122,567 & 21.5 \\
\hline Bamyarı & $2 \in 8,517$ & 7,355 & 2.7 \\
\hline Farah & $=34,621$ & 18,797 & 9.0 \\
\hline Faryad & $58 \approx, 705$ & 54,354 & 3. 4 \\
\hline Ghaznd & 646,623 & $30 \dot{0}, 4 \Sigma 5$ & 4.7 \\
\hline Ghor & 337,992 & 3,974 & 0.3 \\
\hline Helmand & 517,645 & $\varepsilon \epsilon, 646$ & 5.1 \\
\hline Herat & 769,111 & 163,360 & 21.3 \\
\hline Jawz jarı & 588,603 & 54,870 & 3.3 \\
\hline Kabul & $1,8 \in 4,000$ & 313,108 & 43.3 \\
\hline Kandahar & 567,204 & 178,403 & 31.5 \\
\hline Kunarha & 250,132 & 2,089 & 0.8 \\
\hline Kuriduz & 555,437 & 107,131 & 13.3 \\
\hline Laghmari & 310,751 & 3,387 & 1.3 \\
\hline Narigarhar & 745,386 & 56,384 & 7.6 \\
\hline Nimroze & 103,634 & $E, 477$ & 6.2 \\
\hline Farwan & 755,285 & 25,093 & 3.3 \\
\hline Fakt Ika & 245,225 & 1,398 & 0.6 \\
\hline Fakt ıya & 497,503 & 11,415 & 2.3 \\
\hline Safilarigan & $27 \bar{c}, 584$ & 33,016 & 12.1 \\
\hline Takhar & 513,752 & 46,202 & 8.3 \\
\hline Uru=gar & $444,1 E 8$ & 6,863 & 1.5 \\
\hline Zabul & $173,3 \in 2$ & 5,346 & 3.3 \\
\hline
\end{tabular}

Notes: Data refer to the settled population orily. Ur'an inltially referred to the 86 areas recognized by the Central Bureau for Leading Local Orgaris as urban and deserving of muricipal status, but during processing of the census results 23 of these areas were determiried to be "tois small and lackirig the required urban features" to warrant classification as urban. Hence, urban was operationally defaried as 63 areas recognized as such by the Central Bureau for Le 9 Local Organs. These arf unspecified requiremer: size arid urbar features.

Suw: Hfghanistan Ceritral Stat $15 t 365$ Office, 1981, Frelimiriary Results of the First Afghar Fupulation Cerisus, Fublication No. 1, Denographic Statistics, Kabul, arinex tables 1, 1-1, and $1-\Xi$. 
Table 3. Fiplatiju of Urban Flaces, by Size and Size Class: 1373

\begin{tabular}{|c|c|c|c|c|}
\hline \multirow[b]{2}{*}{$31: 20: 0.05$} & \multirow{2}{*}{$\begin{aligned} & \text { Number } \\
& \text { if Clties }\end{aligned}$} & \multicolumn{3}{|c|}{ Populatsor. } \\
\hline & & Nane ef cdty & Total & Percerit \\
\hline Toral urbar areas & $E \bar{J}$ & All urbar places & $1,976,738$ & : ici. ? \\
\hline 500,000 arid Ever & 1 & Kabul & $91 \overline{\dot{1}, 164}$ & $4 E . \Xi$ \\
\hline 100,000 to 499,999 & 3 & $\begin{array}{l}\text { Karidahar } \\
\text { Herat } \\
\text { Mazare Shardf }\end{array}$ & $\begin{array}{l}178,409 \\
140,3=3 \\
103,372\end{array}$ & $\begin{array}{r}3.0 \\
7.1 \\
5.5\end{array}$ \\
\hline 50,000 to 33,933 & 2 & $\begin{array}{l}\text { Jalal Abad } \\
\text { Kuriduz }\end{array}$ & $\begin{array}{l}53,315 \\
53,351\end{array}$ & $\begin{array}{l}\text { E. } 7 \\
\text { E. } 7\end{array}$ \\
\hline$=5,000$ ts 43,333 & $\epsilon$ & $\begin{array}{l}\text { Eaghlan } \\
\text { Maimaria } \\
\text { Pisle Khumri } \\
\text { Ghazni } \\
\text { Kholm } \\
\text { Khan Abad }\end{array}$ & $\begin{array}{l}39,2=8 \\
38,251 \\
31,101 \\
30,425 \\
28,078 \\
36,803\end{array}$ & $\begin{array}{l}3.0 \\
1.9 \\
1.6 \\
1.5 \\
1.4 \\
1.4\end{array}$ \\
\hline 10,000 to 24,397 & 11 & $\begin{array}{l}\text { Charikar } \\
\text { Lashkargah } \\
\text { Taldoan } \\
\text { Sheberghan } \\
\text { Farah } \\
\text { Sare Ful } \\
\text { Andkhoy } \\
\text { Hazrate Emam } \\
\text { Ghoryan } \\
\text { Qalae Zal } \\
\text { Chahab }\end{array}$ & $\begin{array}{l}23,424 \\
21,600 \\
19,9=6 \\
18,995 \\
18,797 \\
15,639 \\
13,137 \\
12,655 \\
12,404 \\
11,632 \\
10,827\end{array}$ & $\begin{array}{l}1.1 \\
1.1 \\
1.0 \\
1.0 \\
1.0 \\
0.8 \\
0.7 \\
0.6 \\
0.5 \\
0 . E \\
0.5\end{array}$ \\
\hline 5,000 to 9,939 & 14 & & 96,666 & 4. 3 \\
\hline 2,501$)$ to 4,999 & 10 & & 37,793 & 1.3 \\
\hline Less than 2,500 & 16 & & 27,858 & $\therefore 4^{\prime}$ \\
\hline
\end{tabular}

Netes: Data refer to the settled population only. Urban initially referred to the 86 areas recognized by the Central Bureau of Leadirig Lica: Orgaris as urbari arid deserving of municipal status, but during processirig if the census results 23 of these areas were determbried to be "too small arid lacking the required urban features" to marrant classification as urbar. Herice, urban was operationally defined as 63 areas recognized as such by the Ceritral Eureau for Leading Local Organs. These areas met urispecified requirenients as to size and urban features.

Source: Afgharistan Ceritral Statistics office, 1381, Frelimiriary Results of the First Afghan Fopilatior, Cerisus, Fublication No. 1, Demographic Statistics, Kabul, aririex table $\Xi$. 


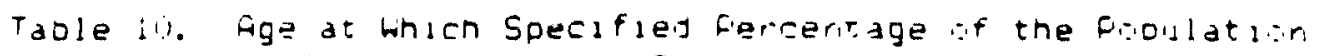

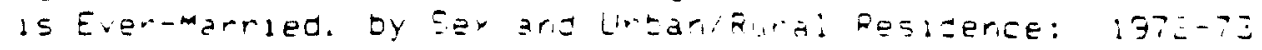

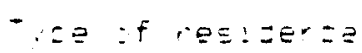

arid ilarlage quartile

Male

Fenaie

ALL AFEISS

¿5 percerit ever-married at age--
I0 percerit ever-married at age--
75 percent ever-narried at age--

18.9 vears

¿2. 5 yoars

E. 1 years
15.9 years

1E. 8 yars

13. E years

IJREAN

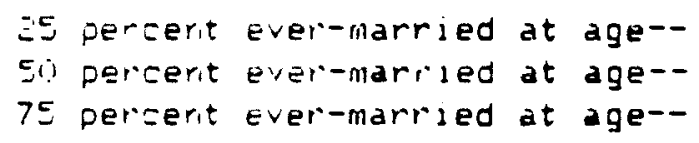

21. 5 years

$=4.7$ years

1E. E yeurs

$\Xi 7.8$ years

18.7 years

¿1. 3 years

RURAL

$$
\begin{aligned}
& \text { is percert ever-married at age-- } \\
& 5 \text { is percerit ever-married at age-- } \\
& 75 \text { percert ever-married at age-- }
\end{aligned}
$$

18. 1 years

¿l. $E$ years

e. 3 years
14.8 years

1E. 4 years

18. 5 years

Note: The age at which the specified perceritage of the pciplation is ever-narried was derlved at the U.S. Bureals of the Cerisus by fitting a Makenali curve ti data frem the 1972-73 demegraphic survey.

Sijurce: Afghanistan Central Statistics Office, 1975, National Demigraphic arid Fallily Guldarice Survey of the Settled Population of Afghanistan, vol. $\Xi$, Tables, Kabul, tables 8.1.0, 8. 2.0, and 8.3.0.

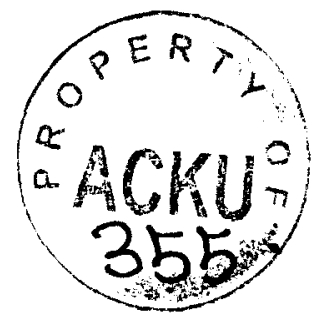


Table 11. Feicerit Married arid Percerit Widiwed fior the Figpulation Ages 15 t: 4 ? rears. by Sex and Urbari/Rural Residence: $137 \bar{\varepsilon}-7 \bar{j}$

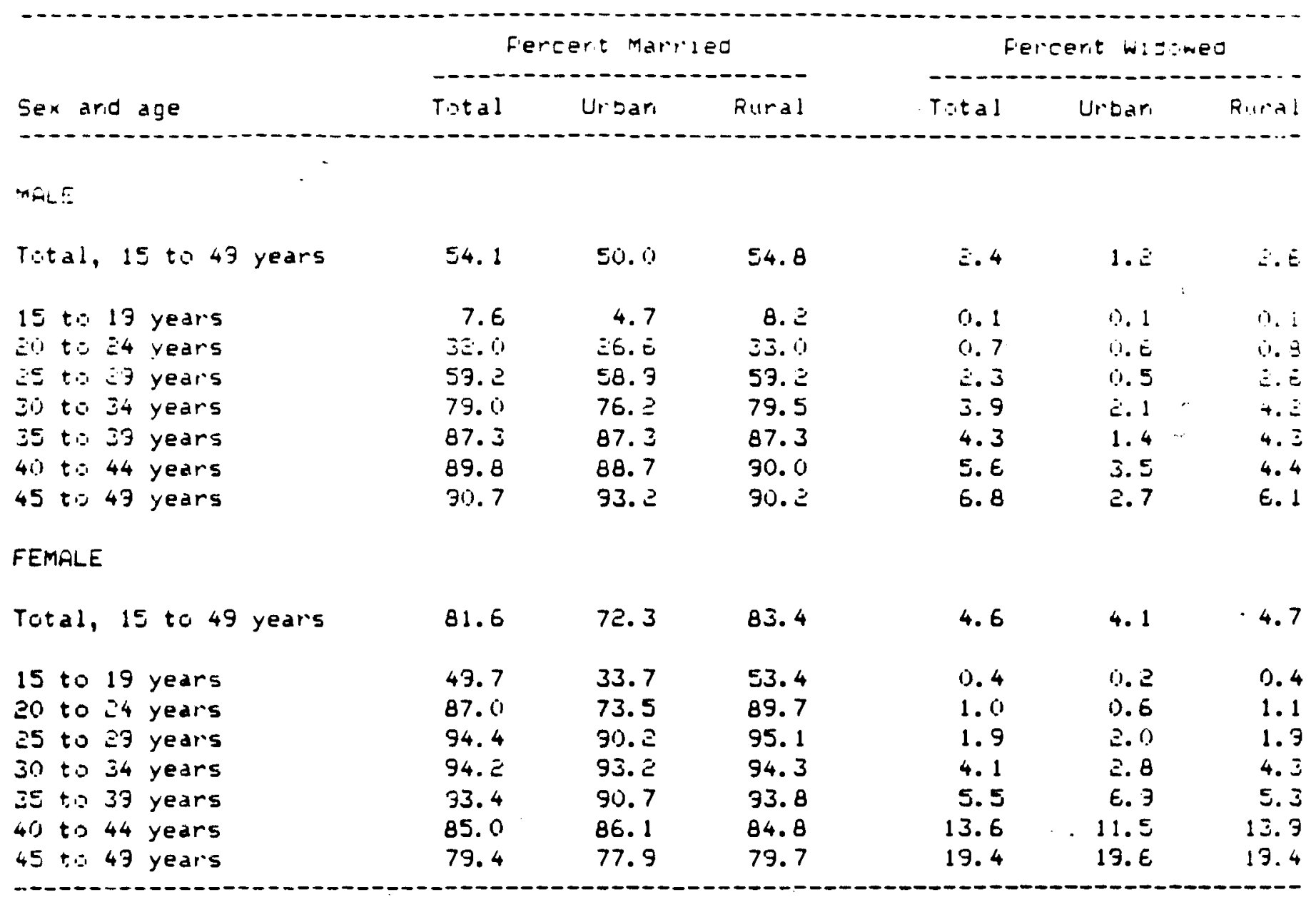

Notes: Ferceritages are based on total marital status minus unknowns. Data refer to the settled population only. Urban refers to all provincial centers, as well as to certain other localities judged by the survey team to be urban on the basis of size, functional complexity, and/or legal status.

Source: Afghanistan Central Statistics Office, 1975, National Demographic and Fainily Guidarice Survey o: the Settled Population of Afghanistan, vol. 3, Tables, Kabul, tables 8.1.0,8.2.0, and 8.3.0. 


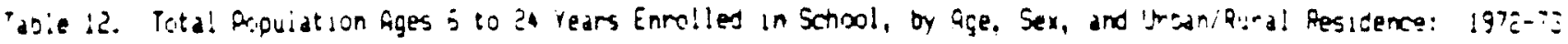
(Fecuiation in thousanos and wy not ado to titlals due to rounding)

\begin{tabular}{|c|c|c|c|c|c|c|}
\hline & & S.th seres & & Male & & Fenale \\
\hline & & Enrolied in senool & & Enrolled in senool & & Enrolled in scmxl \\
\hline Frea and age & $\begin{array}{r}\text { Total } \\
\text { pooulation }\end{array}$ & $\begin{array}{l}\text { Percient } \\
\text { Nimber of total }\end{array}$ & $\begin{array}{r}\text { Total } \\
\text { pepulation }\end{array}$ & $\begin{array}{l}\text { Percent } \\
\text { Number of total }\end{array}$ & $\begin{array}{r}\text { Total } \\
\text { population }\end{array}$ & $\begin{array}{l}\text { Bercent } \\
\text { of intal }\end{array}$ \\
\hline
\end{tabular}

RLL AREAS

Total, ages 6 to 24 years

$4.274 \quad 850 \quad 19.4$

$2,305 \quad 705$

30.6

1,970

125

6. 3

6 to 9 years

$\begin{array}{rrr}1,232 & 228 & 18.5 \\ 1,275 & 386 & 30.2 \\ 941 & 175 & 18.6 \\ 827 & 41 & 5.0\end{array}$

\section{4}

180

28.9

607

47.4

572

530

333

29.1

15 to 19 years

5.0

530

154

8.2

410

381

48
52
20
4

7.9

9.1

5.0

1.1

JREFN

Total, ages 6 to

24 years

$691 \quad 246 \quad 35.6$

$364 \quad 160$

4.0

27786

3. 4

6 to 9 years

10 to 14 years

$\begin{array}{lll}187 & 65 & 34.7\end{array}$

$\begin{array}{lll}205 & 106 & 51.7\end{array}$

$94 \quad 38 \quad 40.4$

$110 \quad 70 \quad 63.0$

$\begin{array}{lll}164 & 60 & 36.7\end{array}$

87

41

47.0

93

27

28.3

15 to 19 years

$136 \quad 15 \quad 11.4$

72

15.8

94

36

38.5

$\pi$

19

25.1

63

6.4

RuRa

Total, ages 6 to 24 years

$\begin{array}{rrr}3,583 & 583 & 16.3 \\ 1,045 & 164 & 15.7 \\ 1,070 & 280 & 26.1 \\ 77 & 114 & 14.7 \\ 691 & 26 & 3.7\end{array}$

1,941

545

28.1

1,642

38

2. 3

6 to 9 years

10 to 14 years

15 to 19 years

69

3.7

$\begin{array}{ll}530 & 142 \\ 593 & 254 \\ 43 & 113 \\ 374 & 25\end{array}$

26.8
4.5
25.5
6.8

514
$4 \pi$
333
317

\begin{tabular}{rr}
21 & 4.1 \\
16 & 3.3 \\
1 & 0.3 \\
121 & 0.1 \\
\hline
\end{tabular}

? - Less than 500 persons.

Source: Afghanistan Central Statistics Office, 1975, National Dewographic and Fanily Guidance Survey of the Settled Population of Afghanistan, Vol. 3, Kabul, tables 10.1.1, 10.1.2, 10.1.3, 10.2.1, 10.2.2, 10.2.3, 10.3.1, 10.3.j, and 10.3.3. 


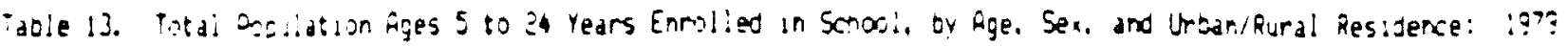
Froulat:ar. ir thousands and wy not ado to totals due to rounding)

\begin{tabular}{|c|c|c|c|c|c|c|c|}
\hline & \multicolumn{2}{|r|}{ Both sexes } & \multicolumn{3}{|c|}{ waie } & \multicolumn{2}{|r|}{ Femaie } \\
\hline & & Enrolled in sctiool & & Errolled & in $5 \cos x$. & & Enrolied in senoo! \\
\hline Arez and age & $\begin{array}{r}\text { Tatal } \\
\text { population }\end{array}$ & $\begin{array}{l}\text { Percent } \\
\text { Number of total }\end{array}$ & $\begin{array}{r}\text { Total } \\
\text { psoulation }\end{array}$ & Nusber & $\begin{array}{l}\text { Percent } \\
\text { of total }\end{array}$ & $\begin{array}{r}\text { Total } \\
\text { populatian }\end{array}$ & $\begin{array}{l}\text { Persent } \\
\text { Nulder of total }\end{array}$ \\
\hline
\end{tabular}

QLL AREAS

Tital. does 5 to 24 years

5 to 9 years

10 to 14 years

15 to 19 years

20 to 24 years

URESW

Total, ages 5 to

24 years

5 to 9 years

10 to 14 years

15 to 19 years

20 to 24 years

Ruar

Total, ages 5 to

$$
24 \text { years }
$$

5 to 9 years

10 to 14 years

15 to 19 years

20 to at years
$5,538 \quad 1,172 \quad 21.2$

1,871

1.554

1,204

910

\begin{abstract}
437
\end{abstract}
481

23.4

$3 ! .0$

17.6

4.6

42
2,696

948

783

574

398
982

341

415

187

39
36.4

36.0

53.0

32.6

9.8
$-$
2,842

323

$\pi 1$

630

518
191

8610.4

67

25

3
6.7

8.6

4.0

0.6

2 - Less than 500 persors.

Source: United Nations, 150i, .... graphic Yearbonk 1963, Naw York, table jo. 
Tate 14. Fercerit Literate, oy Sex, Age, and Urban/Rural Residence:

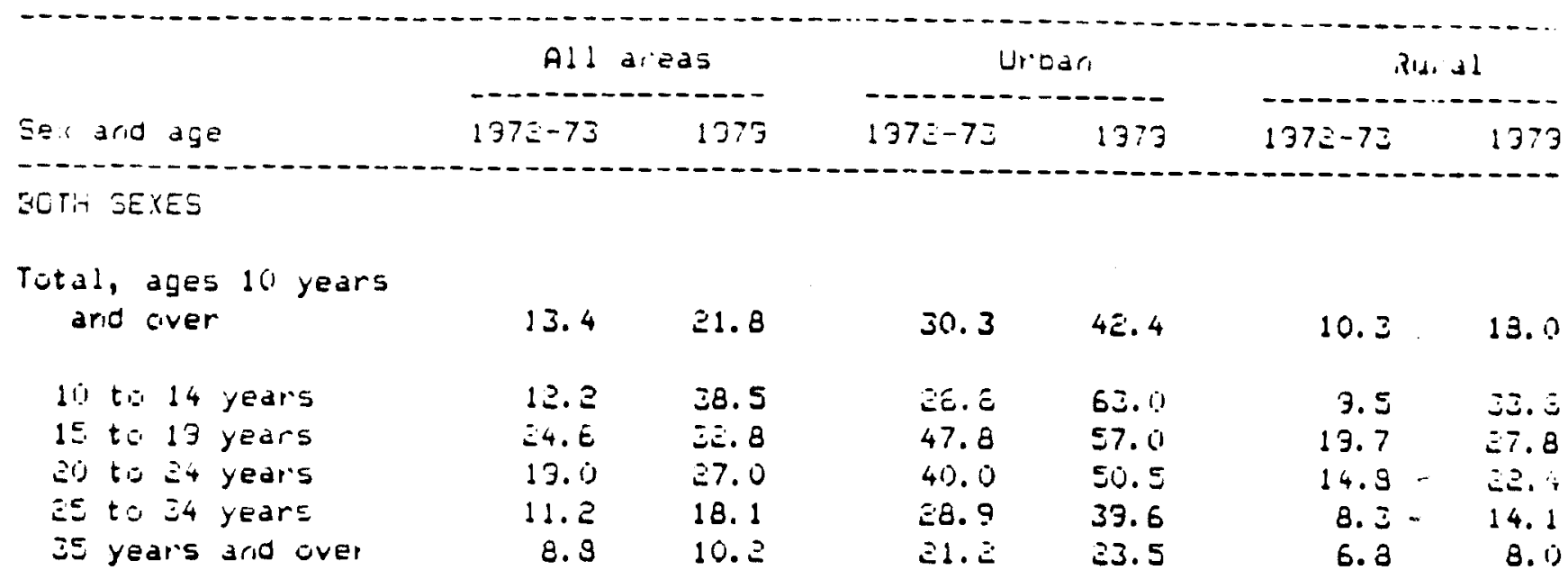

MALE

Total, ages 10 years

\begin{tabular}{|c|c|c|c|c|c|c|}
\hline rid Ever & $\Xi 1 . E$ & $55 . \Xi$ & 41.1 & 56.6 & 18.1 & 31.3 \\
\hline to 14 years & 18.5 & 57.3 & 31.4 & 74.3 & 16.1 & 53.9 \\
\hline to 19 years & $=7.1$ & 48. & 58.1 & 68.6 & 3.0 & 44.3 \\
\hline to $\Xi 4$ years & 30.8 & 42.8 & 52.5 & 66.5 & $\Xi 6 . \varepsilon$ & 38.5 \\
\hline to $\$ 4$ years & 19.7 & 34.2 & $4 \bar{c}^{\prime} .8$ & 59.3 & 15.8 & 23. 1 \\
\hline years arid over & 15.0 & 18.1 & 34.2 & 37.8 & 11.3 & 14.7 \\
\hline
\end{tabular}

FEMALE

Total, ages 10 years and over

3. 3

7.0

17.4

26.3

0.7

3.5

10 to 14 years

4.516 .5

21.0

49. 3

1.2

3. 3

15 to 19 years

8.312 .9

36.0

43.6

2. 0

6.

20 to 24 years

5.1 3.2

25. 3

34.0

1.0

4.2

E: $\$ 0 \quad 34$ years

อ. 3

13.9

20.4

0.6

1. 2

3.8

5.8

0.4

1.8

0.1

i. 5

Notes: Data refer to the settled population only. Literacy is defiried as the abjlity to both read and write, with understandang, a short, simple statemerit on everyday life.

Source: Afgharistan Central Statistics Office, 1975, National Demographic arid Family Guddarice Survey of the Settled Population of Afghanistan, Vul. 3, Tajles, Kabul, tables 3.1.1, 9.1.2, 3.1.3, 9.2.1, 3.2.3, 9.3.2, and 9.3.3; arid Urited Natioris, 1385, Demographic Yearbouk 133j, New York, table 36. 
Table 15. Selected Health Indicators: 1373-80, 1380-81, arid $1381-8 \Xi$

\begin{tabular}{|c|c|c|c|}
\hline !nabatar & $1573-3 i$ & $133 i-31$ & $1381-8=$ \\
\hline 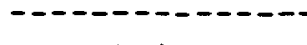 & & & \\
\hline$: \because 5$ f : : $: a ! s$ & $8 \Xi$ & 34 & 83 \\
\hline - Fital deos & 5,413 & $E, 1=3$ & $E, 875$ \\
\hline \multicolumn{4}{|l|}{ Persoris per } \\
\hline hespital bed & 2,817 & $\Xi \beth, E E$ & $\Xi, 01 E$ \\
\hline Fhysiciaris & $1, \Xi \Xi 6$ & $1,1 \geq 1$ & $1, \Xi 15$ \\
\hline \multicolumn{4}{|l|}{ Fersuris per } \\
\hline physiciar & 11,513 & 12,953 & 11,408 \\
\hline \multicolumn{4}{|c|}{ Ais $\times 1$ liary health } \\
\hline persuririel & 5,487 & $\Xi, E 80$ & 4,264 \\
\hline \multicolumn{4}{|l|}{ Fersionis per } \\
\hline $\begin{array}{l}\text { auxiliary hea } \\
\text { persoririel }\end{array}$ & 2,782 & $=, 947$ & 3,350 \\
\hline Pharmacies & 653 & 653 & EJう \\
\hline Fharmacists & 188 & $\Xi 4$ & $\Xi 45$ \\
\hline
\end{tabular}

Source: Rfgharistari Ceritral Statistics Office, 138j, Statistical Yearbook 1360, Kabul, p. 134. 

TECHNICAL APDENIIX

The demographic data used to prepare the projections for the population of Afghanistan and the Afghan refugee population cover the period from 1979 to 1986. Population projections for persons living in Afghanistan and for the separate refugee populations living in Iran and Pakistan are shown for selected years, 1979 to 2050. Fertility and mortality estimates for the Afghan population are based primarily on data from the 1979 census. Fertility and mortality estimates for the refugee populations are based primarily on data for the rural areas of Pakistan. International migration estimates are derived from information on the number of refugees living in Pakistan and Iran as reported for various dates. The sections below on the 1979 census evaluation, fertility, and mortality all pertain to the Afghan population excluding the refugees. The discussion of the estimates of fertility, mortality, and the base populations of refugees in Iran and Pakistan are included in the sertion on international migration.

CFNSIJS EVALUATION

Afghanistan conducted its first population census during the period June 15 to July 4, 1979. Although a full census was planned, circumstances in the country resulted in only about 56 percent of the total population being enumerated. The reported "enumerated" settled population for the entire country is thus an inflated figure, derived by the Central Statistics office of Afghanistan. The method of deriving the inflation factors used is not specified in the census reports, although it is known that differential underenumeration factors were used for urban and rural areas. An additional estimate of 2.5 million nomads is added to the inflated settled population to derive the total country population 
reported by the Central statistics office in the preliminary census publication. The age and sex distribution, as reported in the preliminary report, has apparent Deen smoothed as well using "sctentific techniques." An analysis of this age distribution at the U.S. Bureau of the Census suggests that stable population techniques were used.

Shalikar (1983) completed a master's thesis analyzing the results from the 10-percent sample tabulation of census results. Also, the 1983 United Nations Demographic Yearbook (UNDY) published a "final" age and sex distribution from the census. This distribution is apparently unadjusted, with even different male and female total populations from the adjusted population totals reported in. the preliminary census report. In contrast to the adjusted population discussed In the above paragraph, the Unfted Nations distribution exhibits considerable evidence of digit preference and age misstatement.

Other than the 1979 census and a demographic sample survey conducted in 1972-73, there is little on which to base an estimate of the total stze of the population of Afghanistan. For this reason, the 1979 adjusted census population, by age and sex, as reported in the preliminary census report, is accepted for the estimated settled population for 1979. The official estimate of 2.5 million nomads is also accepted. Nomads were proportionally distributed by age and sex according to the preliminary and adjusted census age and sex distribution.

\section{FERTILITY}

\section{Estimates}

The 1979 census collected information on the number of births occurring in the 12 months prfor to the census date. Data on the number of births to women in 5-year age groups are published in the preliminary census report and the 
1783 HNDY. As noted in the Census Evaluation Section, the age distribution report: in these two sources is different, with the preliminary census distribution appearing to have been smoothed. However, the distribution of births, by age of mother, is identical in both sources. As a result, the age-specific fertility rates (ASFRs) differ in each source. Those ASFRs derived from the preliminary census report imply a total fertility rate (TFR) of 7.1 births per woman while those from the UNחY imply a TFR of 7.6. Nunetheless, the total population and the total number of births in each source is the same, and hence, the implied crude birth rate (CBR) from both sources is 48.1 per 1,000 population.

The birth rate reported in the 1979 census report appears to have resulted from the application of "scientific techniques" (a term used by the Central Statisti,s office to describe how the final census distribution was derived). Specifically, the application of stable population analysis techniques at the U.S. Rureau of Census to the census distritution reported in the UNDY results in a crude birth rate estimate close to the value given in the preliminary report.

Another source of fertility information for Afghanistan is the 1972-73 Afghan Demographic Survey. This source shows a TFR of 6.9 based on an analysis of children-ever-born data and data on births in the 12 months prior to the survey. An earlier U.S. Rureau of the Census (1978) report estimates a TFR of 7.7 based on those data.

The base year (1979) ASFR estimates accepted for the component population projections are the official rates based on the adjusted preliminary census results. These rates imply a TFR Or 7.1 and are consistent with the base population and the estimates of mortality used in the population projections. 
Tot 31 fertility rates for every 5 years, 1985 to 7050 were deriveo oy fitting a logistic curve to the estimated TFR for 1979 and a TFR for 2000 derived by assuming that the change in the TFR from 1979 to 2000 followed the linited Nations' (1986) medium variant trend. The upper and lower asymptotes used to fit the curve were 8.0 and 2.2 , respectively. The patterns for 2000 and 2050 are based on typical age-specific patterns of fertility given the TFR level. The ASFRS for every fifth year 1985 to 1995 and 2005 to 2045 were obtained by linear interpolation of the 1979 ASFRs and the 2000 ASFRs and between the ASFRS for 2000 and for 2050 , respectively. The weights used for interpolating the ASFRs were calculated using the projected TFRs for every fifth year. For intermediate years, annual ASFRs used for the projection series were obtained by linear interpolation of the ASFRs for every fifth year.

MORTALITY

\section{Estimates}

The 1979 census collected information on deaths in the 12 months preceding the census date. The preliminary census report includes age-specific death rates that are based on the adjusted population, by age and sex. Also included are estimated life expectancies at birth for males and females $(41.4$ and 39.9 years, respectively) and infant mortality rates, by sex (188 for males and 175 for females, per 1,000 births). These estimates, as was true for the birth rate estimate discussed in the Fertility Section, are in close agreement with estimated levels based on stable population techniques. 
The estimates cited in the preliminary census report are clearly not the direct result of the enumeration. However, no discussion is included on the method of de:ivation of these estimates. Shalikar (1983) reports the 10-percent sample data on deaths from the census yield a crude death rate (CDR) of 8 per 1, nnO population (compared with a CDR of 22 reported in the preliminary census report). The sample data on deaths also show considerable age heaping and age exaggeration, as would be expected; whereas the preliminary census repart shows a much smoother distribution of deaths, by age, thus strongly providing evidence of the prior adjustment and smoothing of the data shown in the preliminary report

Using adjusted mortality data from the 1972-73 Afghan Demographic Survey, the U.S. Rureau of the Consus (1978) estimeted a crude death rate of 30 per 1,000 population and life expectancies at oirth of 34 and 36 for males and females, respectively.

Considering all the available information, it was declded to accept the 1979 official mortality estimates as the base level of mortality. Although no documentation is provided in the source detailing the methods used to derive the estimates, the levels and patterns provided do not vary greatly from those that would be obtained if indirect techniques were again applied to the available dat.

Life tables, by sex, for 1979 were then derived by accepting the age-specif; mortality rates ( $m x^{\prime} s$ ) from the 1979 preliminary census report for age groups 1 to 4 years through ages 80 years and over. The reported $m x^{\prime} s$ for age under one year, by sex, were adjusted slightly to reproduce the reported infant mortality rate. Separation factors were used from the Coale and Demeny (1966) east region 
The conditions in Afghanistan from 1979 through 1025 were such that mortality has most likely failed to improve and in fact, may have worsened in some years. The lack of rata since 1979 precludes the possibility of assessing the extent to which mortality levels have changed. As a result, the component population projections for the Afghan population, excluding refugees, assume that life expectancy at birth remains constant from 1079 through 1985 .

Life expectancies, by sex, for 1930 through 2050 were initially determined by fitting a logistic curve to the life expectancy values for each sex for 1985 and 2000 . The levels of life expectancy at birth for 2000 were first determined by assuming that the improvement in life expectancy at hirth from 1985 to 2000 would proceed according to the trend implied by the United Nations (1986) 1984 assessment. To fit the logistic curve, the lower asymptote was 25 years for each sex, while the upper asymptotes were 76 years for males and 83 years for females. However, in this curve fitting, the female life expectancy at birth Hoes not exceed that of males until females reach a life expectancy of about 6? years. While males generally do not have higher life expectincy than females, in those countries (predominantly countries in South Asia) that have historically experienced such a situation, a "crossover" of male and female life expertancy at birth has generally been observed when overall life expectancy improved to roughly 55 years. For this reason, the initial fitting of the logistic curve for females was rejected.

The final projected life expectancies at birth, for females, for 1990 to 2050 were derived as follows. Females were assumed to have life expectancy at birth equal to males in the year ?n10 (when male life expectancy was projected to be 53.1). The trend in female life expectancy at birth was then determined by again 
fitting a logistic curve, with the same asymptotic values as used previously. but this time with the 1985 life expectancy at birth and the value of life expectancy for 2710. This alternative method produced a crossover of male and female life expectancy at birth more in agreement with historical observation. INTERNATIONAL MIGRATION

This section describes the estimates and assumptions made for the migration of the Afghan refugee population to Iran and Pakistan. All other net international migration of the country's population is assumed to be zero. Separate component population projections, by age and sex, were made for the refugee population going to Iran and to Pakistan. Assumptions were also made regarding the return of these populations to Afghanistan.

nata on which the base population and trends of total refugee population size are based are primarily from the United Nations High Commissioner for Refugees (UNHCR), the U.S. Department of State, and an unpublished.U.S. Bureau of the Census report, "Detailed Statistics on the Urban and Rural Population of pakistan: 1950 to 2010." The proportional age and sex distributions and the fertility and mortality assumptions of the refugees in Pakistan and Iran are assumed to be the same. The details are given below.

\section{Fertility}

The age-specific fertility rates (ASFRs) of the refugee populations are assumed to remain constant from 1979 through 1983. The total fertility rate (TFR) is assumed to be 7.1 (which is the same as estimated for the population of Afghanistan excluding refugees) during this period. The TFR for 2010 is assumed to be 5.5. This assumption is the same as that used for the report, "Detailed Statistics on the Urban and Rural Population of Pakistan: 1950 to 
2010," hereafter referred to as the Dakistan detailed report. Ifsing the TF? values for 1983 and 2010, a logistic curve was fit to derive projected TFR values every 5 years from 1985 to 2050 . The upper and lower asymptotes assumed in the logistic curve fitting were 8.0 and 2.0 , respectively.

Mortality

Mortality of the refugee populations in 1979 is assumed to be identical to that estimated for the population of Afghanistan excluding refugees. This mortality is assumed to remain constant to 1983. Levels of life expectancy at birth assumed for 2010 were 46.6 for males and 45.9 for females, and correspond to the assumptions made for the refugee population in the pakistan detailed report.

Projected life expectancies at birth, by sex, for every 5 years, 1985 to 2050 , were then derived by fitting a logistic curve to the values for 1983 and 2010 . The lower asymptote used for each sex was 25 years, while the upper asymptote was 75 years for males and 80 years for females.

Emigrants (refugees), 1979 to 1987

Total numbers of migrants to Iran and Pakistan were derived for each year, 1979 to 1987 . For Iran, these totals were derived by fitting a logistic curve to a figure of 600,000 Afghans estimated to he living in Iran in 1979 and IJNHCR estimates for 1983 through 1985. The lower asymptote used to fit the curve was zero and the upper asymptote was 2.1 million. The age distribution of the annual migrants is the same as that derived for the Afghan refugees to Pakistan from the Pakistan detailed report. For Pakistan, the movement out of Afghanistan is based on IJNHCR data through 1981 and official data for $198 ?$ through 1985 as reported by the U.S. nepartment of State. The change in the reported camp population from necember 31, 1985 to May 31, 1986 is accepted as the total 
number of refugees for 1986 , and the 1987 total is derived by extrapolating tho $1985-85$ decline.

Migration Projections, 1988 to 2050

In all projection series, the emigration of refugees to Iran and Pakistan is assumed to be zero after 1987. Varying migration assumptions were made concerning the level and pace of the return migration of refugees to Afghanistan. nne series assumes "no return" of the refugee populations. Another series assumes that beginning in 1990 , there will be a 15 percent annual return of the refugees remaining in Iran and Pakistan until 2010. The small population remaining in 2.011 is assumed to never return to Afghanistan. Finally, an assumption was made that the refugee return will not begin until 1995, but that the remaining refugee population will return at a rate of 20 percent per year until the year 2000 .

49 


ialie A-1. Enumerated Census Fifidation, by Age and Sex: 1973
(Fopulation irithiusarids and may rist add to titals jue t: risuding)

\begin{tabular}{|c|c|c|c|}
\hline$\therefore \varrho$ & Frith sexes & Male & Female \\
\hline All ages & 13,051 & $\varepsilon, 712$ & $E, 337$ \\
\hline 0 t: 4 years & 2,530 & 1,234 & 1,236 \\
\hline$\equiv$ t. 7 years & 1,852 & 942 & 310 \\
\hline 10) to 14 years & 1,542 & 829 & 713 \\
\hline 15 t: 13 years & 1,138 & 673 & 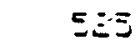 \\
\hline$\Xi 0$ to $\bar{c} 4$ years & 1,038 & 548 & 450 \\
\hline ¿s t: 29 years & 816 & 385 & $4 \equiv 1$ \\
\hline 30 to 34 years & 730 & 324 & $4 \dot{U} E$ \\
\hline 35 to 39 years & 623 & 312 & 311 \\
\hline 40 to 44 years & 638 & 302 & 337 \\
\hline 45 t: 43 years & 447 & 243 & 200 \\
\hline 50 to 54 years & 511 & 265 & 246 \\
\hline 55 to 59 years & 271 & 166 & 105 \\
\hline $6 i)$ to 64 years & 349 & 188 & 161 \\
\hline 65 to $\in 9$ years & 133 & 82 & 52 \\
\hline 70 to 74 years & 190 & 105 & 84 \\
\hline 75 ti. 73 years & 54 & 34 & 20 \\
\hline 80 years and over & 128 & 75 & 53 \\
\hline
\end{tabular}

Notes: Figures exclude nomads, estimated at 2.5 million for the census date. Due to political unrest within the country, not wore than 55 to $E_{0}$ percent of the settled population could be enumerated. Estimates for the settlef population in aruas which were not covered by the enumeration were based on inforwation obtained during the preliminary phases of mapping, cartography, and household prelisting.

Source: United Nations, 1985, Dewographic "earbook 1983, New York, taole 7 . 
Sex arid

age $(x$ te $x+n)$

$q(x, n)$

$d(x, n)$

$m(x, n)$

$I(x)$

$L(x, n)$

$e(x)$

MALE

o te 1 year

1 to 5 years

5 to 10 years

10 to 15 years

15 to 20 years

20 to 25 years

25 to 30 years

30 to 35 years

35 to 40 years

40 to 45 years

45 to 50 years

50 to 55 years

55 to 6.1 years

60 to 65 years

65 to 70 years

70 to 75 years

75 to 80 years

80 years and over

$\begin{array}{rrrrrr}189.3 & 18,930 & 216.8 & 100,000 & 87,317 & 41.6 \\ 111.5 & 9,040 & 30.2 & 81,070 & 273,326 & 50.3 \\ 29.3 & 2,108 & 5.9 & 72,030 & 354,881 & 52.4 \\ 21.8 & 1,525 & 4.4 & 69,322 & 345,798 & 49.9 \\ 26.9 & 1,839 & 5.5 & 68,397 & 337,389 & 45.0 \\ 35.9 & 2,386 & 7.3 & 66,558 & 326,827 & 41.1 \\ 39.0 & 2,501 & 8.0 & 64,172 & 314,609 & 37.6 \\ 44.9 & 2,770 & 9.2 & 61,671 & 301,431 & 34.0 \\ 51.7 & 3,044 & 10.6 & 58,901 & 286,896 & 30.5 \\ 53.3 & 3,312 & 12.2 & 55,857 & 271,007 & 27.0 \\ 68.7 & 3,608 & 14.2 & 52,545 & 253,708 & 23.6 \\ 91.1 & 4,458 & 19.1 & 48,938 & 233,543 & 20.1 \\ 116.9 & 5,201 & 24.8 & 44,479 & 209,394 & 16.9 \\ 163.0 & 6,636 & 36.9 & 39,278 & 179,799 & 13.8 \\ 227.3 & 7,421 & 51.3 & 32,642 & 144,656 & 11.1 \\ 322.2 & 8,126 & 76.8 & 25,221 & 105,790 & 8.6 \\ 437.5 & 7,480 & 112.0 & 17,095 & 66,776 & 6.5 \\ 1000.0 & 9,615 & 219.1 & 9,615 & 43,884 & 4.6\end{array}$

\section{FEMALE}

0 to 1 year

1 to 5 years

5 to 10 years

10 to 15 years

is to 20 years

20 to 25 years

ह5 to 30 years

30 to 35 years

35 to 40 years

40 to 45 years

45 to 50 years

50 to 55 years

55 to 60 years

60 to 65 years

65 to 70 years

70 to 75 years

75 to 80 years

80 years and over

176. 3

111.0

34.7

28.5

39. 1

17,625
9,143
2,544
2,014
2,687

47.4

55.1

EO. 8

65.7

67.7

72. 2

53. 1

120.5

175.6

239.4

344.9

481.9

1000.0
3,128

3,463

3,614

3, 663

\section{3, 510}

4,195

4. 927

6,313
7,096

7,778

7,118

7,654 $\begin{array}{rr}197.1 & 100,000 \\ 30.1 & 82,375 \\ 7.1 & 73,232 \\ 5.8 & 70,688 \\ 8.0 & 68,674\end{array}$

9.7

11.3

12. 6

13.6

14.0

15.0

19.5
25.7

38.5

65,988

62,860

59,397

55,783

34.4

83. 4

12.0
234.3
48,590

45,080
40,885

35,957

29,645

22,549
14,771
7,654
88,543

304,253

348,406

322, 119

305,643

287,951

269,758

234,175

214,911

192, 105

164,005

130,484

93,301
56,063
32,673
39.9

47.4

49.2

45.8

42.1

38. 7

35.5

उद. 5

29. 4

23. 0

19.6

IE. 4

13. 3

10.5

8. 1

6.0

Notes: $x$ exact age at beginning of age interval, in years. $n=$ Length of age interval, in years.

$1,000 \mathrm{~g}(x, n)=$ Rumber of deaths occurring between age $x$ and age $x+n$ per 1,000 persons alive at age $x$, calculated as $1,000 \mathrm{~d}(x, n) / 1(x)$. $d(x, n)$ a Number of deaths occurring between age $x$ and age $x+n$.

$1,000 \mathrm{~m}(x, n)$ - Number of deaths occurring between age $x$ and age $x+n$ per 1,000 persons living between age $x$ and age $x+n$, calculated as

$1,000 \sigma(x, n) / L(x, n)$.

$l(x)=$ Number of persons living at age $x$.

$L(x, n)=$ Number of persons 1 iving befween age $x$ and age $x+n$.

$e(x)$ = Average number of years of life remaining for those alive at age $x$.

Data refer to the settled population only.

Source: Afghanistan Central Statistics Office, 1981, Preliminary Results of the First Rfghan Population Census, Publication No. 1 , Demographic Statistics, Kabul, annex tables 5, 5-1, and $5-2$. 
Tatil A-3. Total Populaticin, ty Marltal Statis, Rog, and cex: 1972-75

(Population in thousands. Flguras may not edd to totols dwe to rounding)

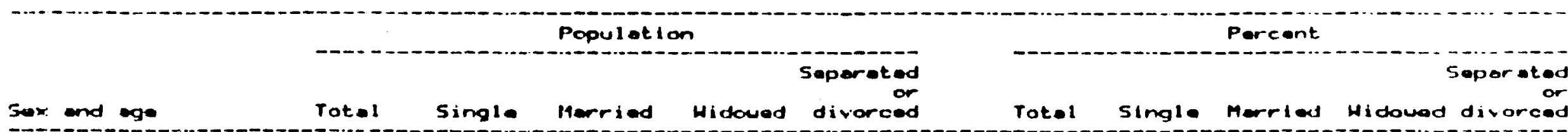

MrE

Total 10 yours

10 to 14 yours

15 to 19 years

20 to 24 years

$2 ! 3$ to 29 years

30 to 34 years

313 to 39 yoars

10 to 44 years

45 to 49 yours

50 to 54 years

55 to 59 years

60 to 64 yom

65 yum sors orid over

Uhthoum oge

FE:MALE

Total. 10 yours

15 to 19 yoors

20 to 24 yours

25 to 29 year:

30 to 34 years

35 to 39 years

10 to 41 years

4 15 to 19 yoars

50 to 54 yeors

55 to 59 years

60 to 64 yeors

66 yeers ard over

Uhthoun oge and ovar

10 to 14 ypars

$\begin{array}{rr}3.720 & 1,736 \\ 703 & 698 \\ 550 & 483 \\ 446 & 300 \\ 349 & 134 \\ 323 & 55 \\ 282 & 25 \\ 243 & 14 \\ 184 & 7 \\ 180 & 3 \\ 114 & 2 \\ 132 & 3 \\ 207 & 3 \\ 24 & 4\end{array}$

1,042

136
$(2)$
1
3
8
13
11
10
10
12
8
17
11
1

914
$5=1$
203
45
12
5
2
3
1
3
1
1
3
1

1,804
36
204
331
321
293
216
169
114
93
14
30
20
5

4
10
143
206
257
246
218
167
165
105
112
162
18

3,033
572
110
381
341
300
253
200
144
150
80
95
117
12

328
$(2)$
2
4
6
12
13
27
28
53
35
58
66
4

2
$(2)$
$(2)$
$(2)$
$(2)$
1
$(2)$
$(2)$
$(2)$
$(2)$
$(2)$
$(2)$
$(2)$
$(2)$

100.0
100.0
100.0
100.0
100.0
100.0
100.0
100.0
100.0
100.0
100.0
100.0
100.0
100.0

46.7
99.1
92.3
67.3
38.5
16.9
8.9
5.7
5.7
1.7
1.4
2.0
1.6
16.4

5
$(2)$
2
$(2)$
$(2)$
$(2)$
$(2)$
$(2)$
1
$(2)$
$(2)$
$(2)$
$(2)$
$(2)$

100.0
100.0
100.0
100.0
100.0
100.0
100.0
100.0
100.0
100.0
100.0
100.0
100.0
100.0

26.9

95. 7

49.3

11.9

3.7

1.6

1.0

1. 3

1.7

1.0

0.9

2.5

100.0

49.6
0.6
7.6
32.0
59.2
79.0
87.3
89.8
90.7
91.5
91.6
95.4
78.4
77.2

0.6

7.6
32.0

59.2

79.0

87.3

90.7

91.5

70.4

77.2

62.2

10.7

0.2

6.3

49.7

94.0

94.2

94.2

95.4

79.1

62.3

65.1

40.7

23.9

10.9

(2)

0.1

1.0

1.9

4.1

5.5
13.6

13.6
19.4

35.6

43.5

38.2

73.4

36.5

(2)

(Z)

(2)

0.2

0.1

(2)

(2)

(2)

(2)

0.1

0.3
$(2)$

2 - Volue is less then ona-helf of the smallest witt shown in givan cotagory.

Soumce, nfghonistan Cantrel statistics offlce, 1975. Nationel Oemographic end Family fiuidorice Survay of the Sottled fopulation of Afothanistan, Ual, 5, Toblas, Kabul, tntile B.1.0. 
Totil A-4. Uition Fopulaticn, ty Marital Status, Roe, and 5ax: 1972-i'3

(l'cpulation lil thousands. Figuras inag not adel to totals due te rounding)

Populetion

Percent

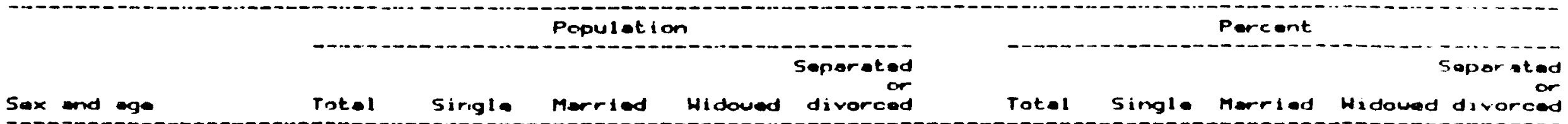

MrRe

Total, 10 yours

Total: 10

$\begin{array}{rrr}562 & 289 & 261 \\ 110 & 110 & (2) \\ 87 & 93 & 1 \\ 72 & 52 & 19 \\ 54 & 22 & 32 \\ 44 & 10 & 53 \\ 39 & 4 & 34 \\ 34 & 3 & 30 \\ 28 & 1 & 26 \\ 26 & 1 & 23 \\ 16 & 1 & 15 \\ 19 & (2) & 17 \\ 28 & 1 & 23 \\ 4 & 1 & 5\end{array}$

12
$(2)$
$(2)$
$(2)$
$(2)$
1
1
1
1
1
1
2
1
$(2)$

$(2)$
$(2)$
$(2)$
$(2)$
$(2)$
$(2)$
$(2)$
$(2)$
$(2)$
$(2)$
$(2)$
$(2)$
$(2)$
$(2)$

$$
\begin{aligned}
& 100.0 \\
& 100.0 \\
& 100.0 \\
& 100.0 \\
& 100.0 \\
& 100.0 \\
& 100.0 \\
& 100.0 \\
& 100.0 \\
& 100.0 \\
& 100.0 \\
& 100.0 \\
& 100.0 \\
& 100.0
\end{aligned}
$$

51.4

46.4

2.2

(2)

10 to 14 yeors

20 to 19 years

20 to 24 years

25 to 29 years

38 to 59 years

10 to 44 yours

45 to 49 years

30 to 54 yeors

55 to 59 yeors

68 year: and over

Unknown oge

FEMARE

Totel, 10 yaurs
and over

$\begin{array}{rr}470 & 168 \\ 94 & 92 \\ 77 & 51 \\ 63 & 16 \\ 49 & 1 \\ 42 & 2 \\ 34 & 1 \\ 29 & 1 \\ 23 & (2) \\ 19 & (2) \\ 12 & (2) \\ 12 & (2) \\ 15 & (2) \\ 1 & (2)\end{array}$

$\begin{array}{rr}239 & 42 \\ 2 & (2) \\ 26 & (2) \\ 47 & (2) \\ 44 & 1 \\ 39 & 1 \\ 31 & 2 \\ 28 & 3 \\ 18 & 4 \\ 12 & 6 \\ 6 & 6 \\ 5 & 6 \\ 1 & 11 \\ 1 & (2)\end{array}$

1
$(2)$
$(2)$
$(2)$
$(2)$
$(2)$
$(2)$
$(2)$
$(2)$
$(2)$
$(2)$
$(2)$
$(2)$
$(2)$

99.8

72.8

0. 2

40.5

26.6

21.8

11. 3

4.1

4.1

5. 2

2.2

16.5

58.9

76.2

a). 3

9日.?

93.2

90.7

90.3

89. 9

82.2
01.3

(2)

0.1

O.E.

2. 1

1.4

3. 5

2.7

5. 5

9. 0

14.1

2.2

(2)

(2)

(2)

(2)

(2)

0.1

(2)

0.1

(2)

(2)

(2)

10 to 14 years

15 to 19 years

20 to 24 yours

20 to 29 yeers

30 to 34 veers

40 to 44 uners

45 to 49 yeer:

50 to 54 years

56 to 59 years

66 yeers ond over

Uhiknown orge

$\begin{array}{rr}68 & 25 \\ 92 & \\ 51 & 25 \\ 16 & 4 \\ 1 & 4 \\ 2 & 39 \\ 1 & 3 \\ 1 & 2 \\ (2) & 1 \\ (2) & 1 \\ (2) & \\ (2) & \\ (2) & \end{array}$

100.0
100.0
100.0
100.0
100.0
100.0
100.0
100.0
100.0
100.0
100.0
100.0
100.0
100.0

30.7
97.9
66.0
25.8
7.6
3.7
2.4
2.0
2.0
2.5
1.7
1.6
5.0
15.9

55.1
2.1
35.7
75.6
90.2
93.2
90.7
86.1
77.9
65.9
49.8
43.0
27.2
46.1

9.0

0.2

(z)

0.2

0.6

2.0

2. 9

6.9

11.8

19.6

31.4

48.1

54.9

69.0

(2)

0.1

0. 1

0.2

(2)

0.4

0.4

0.2

0.7

$100.0 \quad 15.9 \quad 46.1$

2 - Value is less thon ono-helf of the smollest wnit shown in a given cetagory.

Sourcer nfghnisten Contrel statistics office, 1975, Nationel Demographio ond family fiuidence

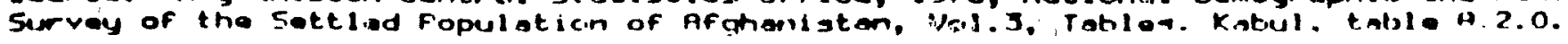




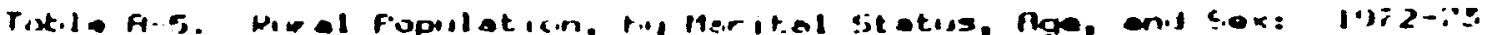

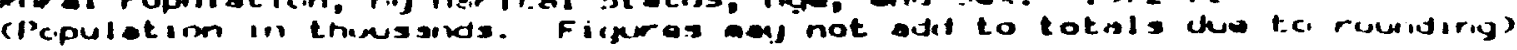

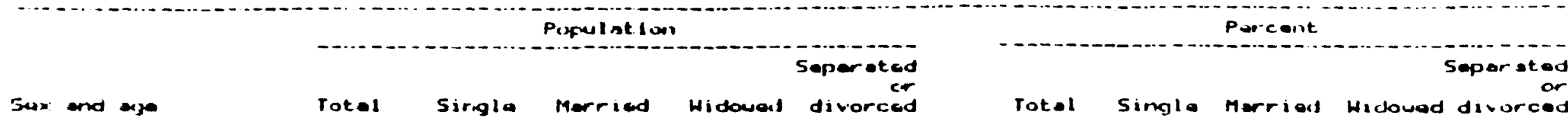

Totel

irigla Merried Singla Merrial Widowed divorced

MYE

Totol, 10 yours and over

11) to 14 yeers

115 to 19 isurs

20 to 24 yeitor.

30 to 34 yeors

$3 ! 5$ to 39 yeers

10 to 44 yentors

$4 ! 5$ to 49 yoers

50 to Et yoers

$5 ! 5$ to 89 ywars

60 to E. years

$6 ! 5$ yeors ard over

Uithinorn age

FI:MARE Totel, 10 yoars
and over

10 to 14 yours

18 to 19 ywors

20 to 24 ywer.

35 to 29 your:

$3 ! 3$ to 39 yeers

40 to 44 years

15 to 19 yeer:

50 to 54 yeers

60 to 64 yours

513 yemrs and ovor

libinown oge

$\begin{array}{rr}3.157 & 1.440 \\ 593 & 580 \\ 143 & 406 \\ 374 & 240 \\ 295 & 113 \\ 281 & 18 \\ 242 & 20 \\ 209 & 11 \\ 156 & 6 \\ 155 & 2 \\ 59 & 1 \\ 113 & 2 \\ 179 & 2 \\ 19 & 3\end{array}$

1.581
36
123
173
223
212
187
111
112
90
95
139
14

124
$(2)$
1
3
8
12
10
9
10
11
18
38
1

2
$(2)$
$(2)$
$(2)$
$(2)$
1
$(2)$
$(2)$
$(2)$
$(2)$
$(2)$
$(2)$
$(2)$
$(2)$

100.0
100.0
100.0
100.0
100.0
100.0
100.0
100.0
100.0
100.0
100.0
100.0
100.0
100.0

45.9
39.3
91.7
$66 . .2$
36.2
16.1
61.4
5.1
1.7
1.3
1.1
2.0
1.3
16.4

$$
\begin{array}{r}
50.1 \\
0.7 \\
8.2 \\
33.0 \\
59.2 \\
79.5 \\
97.3 \\
90.0 \\
90.2 \\
91.6 \\
91.9 \\
84.7 \\
77.9 \\
76.2
\end{array}
$$

3. 9

o. 1

76.2

(2)

0.1

2.

4.

4.9

6.1

7.1

7.1

20. 13

6.5

(2)

(2)

(2)

0.2

0. 1

0.2

( 2$)$

(Z)

(2)

0.2

0.4

2,863
477
335
317
292
258
159
171
121
131
68
83
101
11

$\begin{array}{rr}646 & 1,626 \\ 142 & 34 \\ 152 & 178 \\ 29 & 284 \\ 3 & 278 \\ 3 & 273 \\ 2 & 187 \\ 2 & 144 \\ 123 & 97 \\ 2 & 81 \\ 1 & 39 \\ 1 & 33 \\ 3 & 24 \\ 1 & 4\end{array}$

$\begin{array}{rr}283 & 5 \\ (2) & (2) \\ 1 & (2) \\ 1 & (2) \\ 8 & (2) \\ 11 & (2) \\ 11 & (2) \\ 24 & 1 \\ 23 & (2) \\ 48 & (2) \\ 29 & (2) \\ 49 & \end{array}$

25.3

65.6

11.0

0.2

92.9

9.1

3.0

1.3
0.0

0.8
1.2

0.2

1.6

0.9

0.8

(2)

0.1

(2)

0.1

(2)

1.50 .1

$\begin{array}{rr}5.5 & 0.1 \\ 13.5 & 0.1\end{array}$

19.10 .7

36.20 .3

$\begin{array}{ll}12.4 & 0.6 \\ 50.6 & 0.2\end{array}$

$34.0 \quad 0.2$ $\begin{array}{lrrrr}100.0 & 2.5 & 23.4 & 74.0 & 0.1 \\ 100.0 & 12.0 & 49.3 & 36.1 & 1.8\end{array}$
7.1

63.4

95. 1

94.3

93.8

Q4. 4

79.7
61.0

61.0

10.1

23.4 $\begin{array}{lrrrr}100.0 & 2.5 & 23.4 & 74.0 & 0.1 \\ 100.0 & 12.0 & 49.3 & 36.1 & 1.8\end{array}$

2. Volue is less than onw-helf of thw mallent wit showi in aiven catagory.

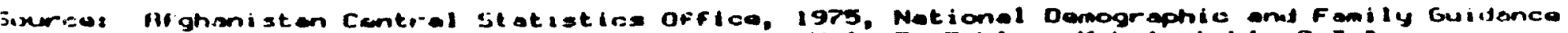

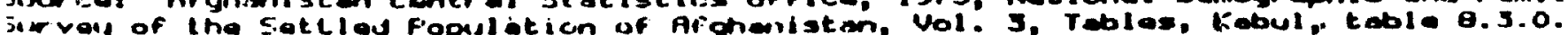


Taole fo. Total Literate Population, oy ane and Sex: $1972-73$ and 1979

(Fopulation in thousands. Fagures wy not add to totals due to rounding)

\begin{tabular}{|c|c|c|c|c|c|c|c|c|c|}
\hline \multirow[b]{3}{*}{ Year and age } & \multicolumn{3}{|c|}{ Botn sexes } & \multicolumn{3}{|c|}{ Male } & \multicolumn{3}{|c|}{ Fende } \\
\hline & & Laterate & opulation & & Laterate & opulation & & Laterate & opulation \\
\hline & $\begin{array}{l}\text { Total } \\
\text { population }\end{array}$ & Thers & $\begin{array}{l}\text { Percent } \\
\text { of total }\end{array}$ & $\begin{array}{r}\text { Total } \\
\text { poovlation }\end{array}$ & Nember & $\begin{array}{l}\text { Percent } \\
\text { of total }\end{array}$ & $\begin{array}{r}\text { Total } \\
\text { population }\end{array}$ & numer & $\begin{array}{l}\text { Dercent } \\
\text { of total }\end{array}$ \\
\hline
\end{tabular}

$1972-73$

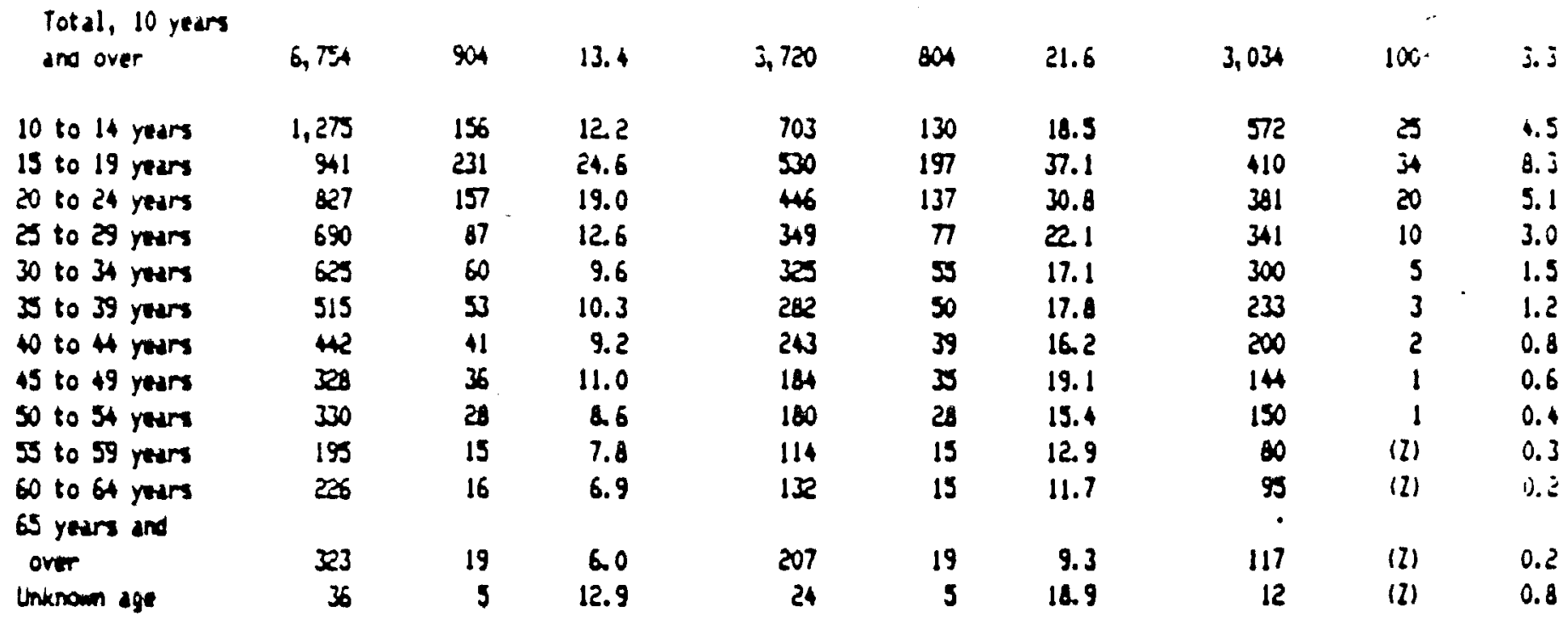

1979

\begin{tabular}{|c|c|c|c|c|c|c|c|c|c|}
\hline and over & 8,669 & 1,007 & 21.8 & 4,536 & 1,599 & 35.2 & 4,133 & 288 & 7.0 \\
\hline 10 to 14 mars & 1,542 & 593 & $36 .:$ & 829 & 475 & 57.3 & 713 & 118 & 16.5 \\
\hline 15 to 19 yours & 1,198 & 382 & 32.8 & 673 & 325 & 4.2 & 525 & 68 & 12.9 \\
\hline 30 to 24 yours & 1,038 & 200 & 27.0 & 548 & 230 & 20.8 & 490 & 45 & 9.2 \\
\hline 25 to 29 rears & 816 & 174 & 21.4 & 385 & 148 & 38.5 & 431 & 26 & 6. 1 \\
\hline 30 to 34 years & 730 & 106 & 14.5 & 324 & 9 & 29.0 & 406 & 12 & j. 0 \\
\hline So to years & $1, \mathbf{2 6 1}$ & 14 & 11.7 & 613 & 136 & 22.2 & 648 & 11 & 1.7 \\
\hline 45 to 54 yeurs & 20 & 104 & 10.8 & 514 & 99 & 19.2 & 445 & 5 & 1.1 \\
\hline $\begin{array}{l}55 \text { to } 64 \text { years } \\
65 \text { years and }\end{array}$ & 620 & 30 & 49 & 354 & 5 & 15.1 & 286 & 2 & 0.7 \\
\hline ont & $\operatorname{sos}$ & 30 & 6.9 & 297 & 34 & 11.4 & 209 & 1 & 0.6 \\
\hline
\end{tabular}

2- Less than 500 persons.

Source: Afghanistan Central Statistics Office, 1975, Kational Dewographic and Fauily Guidance Survey of the Settled Population of Afghanistan, Vol. 3, Tables, Kabul, tables 9.1.1, 9.1.2, and 9.1.3; and united Kations, 19a5, Dewographic Yearbook 1983, new York, table 36. 
iatie 7-7. Urban Literate Population, by Age and Sex: 1972-73 and 1979

(Population in thousands. Figures way not ado to totals due to rouncing)

Year and age population Number of total $\begin{gathered}\text { Both sexes } \\ \begin{array}{r}\text { Total } \\ \text { Literate population }\end{array}\end{gathered}$

$1972-73$

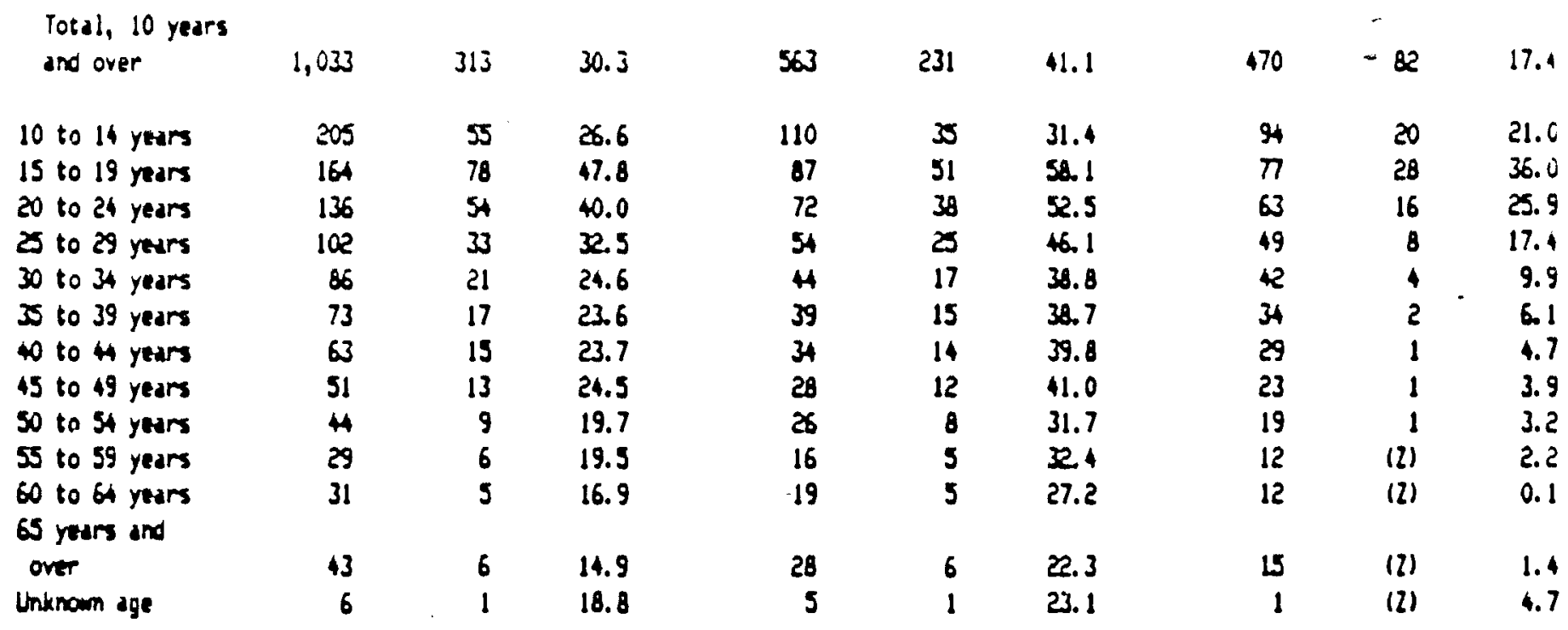

1979

\begin{tabular}{|c|c|c|c|c|c|c|c|c|c|}
\hline and over & 1,346 & 570 & 42.4 & 714 & 404 & 56.6 & 620 & 166 & 26.3 \\
\hline 10 to 14 years & 257 & 162 & 63.0 & 138 & 103 & 74.3 & 119 & 60 & 49.9 \\
\hline 15 to 19 years & 204 & 116 & 57.0 & 109 & 75 & 68.6 & 95 & 41 & 43.6 \\
\hline 20 to 24 years & 167 & 4 & 50.5 & 85 & 56 & 66.5 & 22 & 20 & 34.0 \\
\hline 25 to 29 rears & 133 & 59 & 4.2 & 66 & 42 & 63.1 & 67 & 17 & 25.4 \\
\hline 30 to 34 years & 110 & $\boldsymbol{3}$ & 34.1 & 34 & 29 & 54.6 & 56 & 8 & 14.5 \\
\hline 35 to 4 years & 163 & 51 & 27.9 & 95 & 43 & 45.7 & 88 & 8 & 8.8 \\
\hline 45 to 54 years & 133 & 33 & 24.4 & 74 & 30 & 4.1 & 60 & 3 & 4.8 \\
\hline $\begin{array}{l}55 \text { to } 64 \text { years } \\
65 \text { years and }\end{array}$ & $\$$ & 17 & 19.7 & 50 & 16 & 31.6 & 36 & 1 & \\
\hline over & 74 & $\|$ & 15.1 & 4 & 11 & 24.0 & 30 & 1 & 2.1 \\
\hline
\end{tabular}

2 - Less than 500 persons.

Source: Afghanistan Central Statisics Office, 1975, Kational Dewographic and Fadily Guidance Survey of the Settled Population of Afghanistam Vol. 3, Tables, Kabul, tables 9.2.1 through 9.2.3; and United Nations, 1885, Desographic Yearbook 1983, New York, table 36. 
Tatle A-8. Riral Literate inpulation, by Age and Sex: 1972-73 and 1979

(Fopulation in thousands. Figures wy not add to sotals due to rounding)

\begin{tabular}{|c|c|c|c|c|c|c|c|c|c|}
\hline & \multicolumn{3}{|c|}{ Boin sexes } & \multicolumn{3}{|c|}{ male } & \multicolumn{3}{|c|}{ Fewale } \\
\hline & & Literate & ooulation & & Literate & opulation & & Laterate & ooulation \\
\hline & Tutal & & Fercent & $\operatorname{Tot} a 1$ & & Percent & Total & & Eercent \\
\hline rear anc ag̣e & popidation & Ninber & of total & population & Nunber & of total & population & Nunoer & of total \\
\hline
\end{tabular}

$1972-73$

\begin{tabular}{|c|c|c|c|c|c|c|c|c|c|}
\hline and over & 5,721 & 591 & 10.3 & 3,157 & 572 & 18.1 & 2,563 & .19 & 0.7 \\
\hline 10 to 14 vears & 1,070 & 101 & 9.5 & 593 & $x$ & 16.1 & $4 \pi$ & 6 & 1.2 \\
\hline 15 to 19 years & $m$ & 153 & 19.7 & 443 & 146 & 33.0 & 333 & 7 & 2.0 \\
\hline 20 to 24 years & 691 & 102 & 14.8 & 374 & 99 & 26.6 & 317 & 3 & 1.0 \\
\hline 25 to 29 years & 588 & 54 & 9.2 & 295 & 52 & 17.8 & 298 & 2 & 0.6 \\
\hline 30 to 34 years & 539 & 39 & 7.2 & 281 & 38 & 13.7 & 258 & (2) & 0.2 \\
\hline 35 to 39 years & 442 & 36 & 8.0 & 242 & 35 & 14.4 & 199 & 1 & 0.4 \\
\hline 40 to rears & 379 & $a b$ & 6.8 & 208 & $\alpha$ & 12.4 & 171 & (2) & 0.1 \\
\hline 45 to 49 years & $2 \pi$ & 24 & 8.5 & 156 & 24 & 15.1 & 121 & (z) & (l) \\
\hline 50 to 54 years & 286 & 20 & 6.9 & 155 & 20 & 12.7 & 131 & (2) & (2) \\
\hline 55 to 59 years & 166 & 9 & 5.7 & 98 & 9 & 9.7 & 68 & (2) & (2) \\
\hline $\begin{array}{l}60 \text { to } 64 \text { years } \\
65 \text { years and }\end{array}$ & 196 & 10 & 5.3 & 113 & 10 & 9.1 & 83 & (2) & 0.2 \\
\hline over & $2 B O$ & 13 & 4.7 & 179 & 13 & 7.3 & 101. & (2) & (2) \\
\hline Unknown age & 30 & 3 & 11.7 & 19 & 3 & 2.0 & 11 & (2) & 0.3 \\
\hline
\end{tabular}

\begin{tabular}{|c|c|c|c|c|c|c|c|c|c|}
\hline and over & 7,324 & 1,317 & 18.0 & 3,823 & 1,180 & 31.3 & 3,501 & 122 & 3.5 \\
\hline 10 to 14 years & 1,285 & 431 & 33.6 & 691 & 373 & 53.9 & 594 & 58 & 9.8 \\
\hline 15 to 19 years & 994 & 276 & 27.8 & 564 & 250 & 4.3 & 430 & 27 & 6.2 \\
\hline 20 to 24 yeurs & 871 & 156 & 22.4 & 463 & 178 & 38.5 & 408 & 17 & 4.2 \\
\hline 25 to 29 years & 683 & 116 & 17.0 & 319 & 107 & 33.5 & 364 & 9 & 2.6 \\
\hline jo to 34 years & 621 & 69 & 11.0 & 270 & 65 & 23.9 & 350 & 4 & 1.1 \\
\hline 35 to years & 1,078 & 97 & 9.0 & 519 & 93 & 17.9 & 560 & 4 & 0.6 \\
\hline 45 to 54 yeurs & 826 & 71 & 8.6 & 40 & 69 & 15.7 & 386 & 2 & 0.5 \\
\hline $\begin{array}{l}55 \text { to } 64 \text { years } \\
65 \text { years and }\end{array}$ & 534 & 39 & 7.2 & 304 & 38 & 12.4 & 230 & 1 & 0.4 \\
\hline over & 431 & 24 & 5.5 & 253 & 23 & 9.2 & 179 & 1 & 0.3 \\
\hline
\end{tabular}

I- Less than 500 persons or less than .05 percent.

Source: Afghanistan Central Statistics Office, 1975, National Dewographic and Fanily Guidance Survey of the Settled Dopulation of Afghanistan, Vol. 3, Tables, Kabul, tables 9.3.1 through 9.3.3; and United Nations, 1985, Dewographic Yearbook 1983, New York, table 36. 
Table A-9. Selected Population, Health, and Education Indicators, by Province: 1901-82

\begin{tabular}{|c|c|c|c|c|c|c|c|c|c|}
\hline \multirow[b]{2}{*}{ Province } & \multirow[b]{2}{*}{$\begin{array}{l}\text { Peicent } \\
\text { urban }\end{array}$} & \multirow{2}{*}{$\begin{array}{r}\text { Persons } \\
\text { per } \\
\text { square } \\
\text { kiloweter }\end{array}$} & \multirow{2}{*}{$\begin{array}{l}\text { Student/ } \\
\text { Teucher } \\
\text { ratio }\end{array}$} & \multicolumn{6}{|c|}{ Total number of persons per } \\
\hline & & & & St went & School & Tewcher & hospital & $\begin{array}{l}\text { Hospital } \\
\text { bed }\end{array}$ & Phrsician \\
\hline Total & 15.8 & 21 & 29.9 & 11 & 3,219 & 331 & 229,130 & 3,191 & 12,453 \\
\hline Kabul & 68.3 & 331 & 29.8 & 5 & 4,729 & 139 & 108,422 & 595 & 1,924 \\
\hline Kapisa & .5 & 140 & २ร. 8 & 9 & 2,340 & $2 \pi$ & 262,039 & $x_{,}, 204$ & $\cdots 65,510$ \\
\hline Parnun & 4.8 & 56 & 41.8 & 10 & 2,576 & +2 & 527,987 & 17,600 & $\therefore \quad 65,988$ \\
\hline Haroak & .7 & 33 & 26.0 & 16 & 3,624 & 419 & 150,390 & 10,743 & 50,133 \\
\hline Logar & 2.3 & 49 & 27.1 & 11 & 2,357 & 298 & 236,234 & 11,312 & 45,247 \\
\hline Enazni & 4.7 & $\not 9$ & 27.5 & 16 & 3,779 & 435 & 676,416 & 16,910 & 67,642 \\
\hline Dakt1a & 2.4 & 53 & 28.8 & 13 & 3,986 & 364 & 16,566 & 5,329 & $28,1 x$ \\
\hline Manganthar & 7.7 & 103 & 31.9 & 12 & 4,416 & 386 & 195,405 & 1,780 & 4882 \\
\hline Lagrmen & 1.3 & 45 & 29.9 & 9 & 3,611 & 284 & 325,010 & 16,251 & 81,253 \\
\hline Kunertad & .8 & ఒక & 26. 1 & 9 & 1,645 & 253 & 261,604 & 13,000 & 32,701 \\
\hline Buductitun & 2.0 & 11 & 35.6 & 13 & 2,491 & 456 & 520,620 & 17,354 & 57,047 \\
\hline Takther & 8.9 & 4 & 29.9 & $1 ?$ & 3,420 & 522 & 271,509 & 13,595 & 108764 \\
\hline Baghlen & 15.3 & 30 & 29.7 & 14 & 3,171 & 102 & 258,461 & 6,092 & 51,692 \\
\hline Kundus & 19.5 & 74 & 28.5 & 14 & 3,900 & 397 & 19,200 & 10,593 & 116,520 \\
\hline Sumangan & 12.7 & 18 & ๔. 8 & 16 & 2,301 & 123 & 273,04 & 9,129 & 273,054 \\
\hline Balkh & 21.5 & 40 & 29.4 & 12 & 2,250 & 365 & 609,590 & 9,378 & 33,866 \\
\hline Jauz jun & 9.4 & 24 & 40.2 & 15 & 3,802 & 601 & 307,959 & $13 ; 686$ & 76,985 \\
\hline Faryab & 9.5 & 27 & 32.2 & 12 & 3,192 & 391 & 304,102 & 12,19 & 50,609 \\
\hline Buoghis & 2.3 & 11 & 27.3 & 19 & 3,394 & 532 & 122,173 & 4,145 & 40,724 \\
\hline herat & 21.7 & 13 & 27.6 & 13 & 3,514 & 358 & 202,006 & 5,001 & 20,257 \\
\hline Furch & 8.1 & 5 & 29.6 & 9 & 2,152 & 265 & 245,474 & 4182 & 49,090 \\
\hline Mimar & 6.3 & 3 & 26.2 & 10 & 1,594 & 276 & 106,410 & 5,121 & 15,46 \\
\hline theland & 5.2 & 9 & 29.6 & 17 & 3,471 & 456 & 51,500 & 8,331 & 108,302 \\
\hline Kandunar & 38.0 & 13 & 23.1 & 15 & 3,417 & 381 & 597,54 & 2,300 & 37,372 \\
\hline lan! & 3.3 & 11 & 20.1 & 22 & 2,208 & 40 & 167,612 & 9,381 & 31,269 \\
\hline Urozgen & 1.6 & 16 & 41.5 & 2. & 3,601 & 236 & 464,506 & 23,230 & $x_{1} 911$ \\
\hline Ehor & .9 & 9 & 220 & 18 & 2, 281 & 391 & 300,49 & 17,673 & 58,916 \\
\hline Buryan & 2.8 & 16 & 31.9 & 15 & 2,577 & 474 & 280,059 & 18,724 & 70,215 \\
\hline Paktika & .6 & 13 & 3.6 & 16 & 3,664 & 590 & 128,235 & 10,259 & 64,118 \\
\hline
\end{tabular}

Notes: Education date refer to general education halth indicator data refer to hinigary of Public halth facilities.

Source: Afghanistan Central Statistics Offica, 1963, Statistical Yearbook 1350, Kabul, pas 10-41, 51, 135-136, and 145-146. 


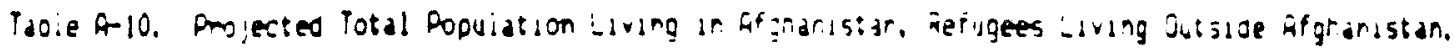
anc iencentage of Total Afgnan Fopuia:ije Giving 01.tside afgnanistan: 1880 to 5010 (Droulation in thousands)

\begin{tabular}{|c|c|c|c|c|c|c|c|c|}
\hline \multirow{2}{*}{$\frac{\text { rear }}{i 300}$} & \multicolumn{2}{|c|}{$\begin{array}{c}\text { Total pooulation } \\
\text { ilving lif } \\
\text { ingananistan }\end{array}$} & \multicolumn{3}{|c|}{$\begin{array}{l}\text { Tistal iefugees } \\
\text {-1ring in } \\
\text { Baxistan and lian }\end{array}$} & \multicolumn{3}{|c|}{$\begin{array}{l}\text { Fercent of tctal } \\
\text { Afọnan soouiation } \\
\text { idving as refugees }\end{array}$} \\
\hline & 14,385 & & & 1,189 & & & 7.35 & : \\
\hline 1382 & 13.642 & & & j. 355 & & & 19.76 & \\
\hline 1304 & 15.817 & & & 0.1228 & & & 2.51 & \\
\hline i 3800 & 15.381 & & & 4.743 & & & 25.33 & \\
\hline i 300 & 14.481 & & & 5,167 & & & 26.30 & - \\
\hline $\begin{array}{l}\text { noturn } \\
\text { res }\end{array}$ & $\begin{array}{r}15 x \\
\text { return }\end{array}$ & $\begin{array}{l}\text { Iix } \\
\text { return }\end{array}$ & $\begin{array}{l}\text { Noturn } \\
\text { retur }\end{array}$ & $\begin{array}{r}15 x \\
\text { return }\end{array}$ & $\begin{array}{l}20 x \\
\text { return }\end{array}$ & $\begin{array}{l}\text { to } \\
\text { return }\end{array}$ & $\begin{array}{r}15 x \\
\text { return }\end{array}$ & $\begin{array}{l}\text { 20x } \\
\text { return }\end{array}$ \\
\hline 15,179 & $: 5,532$ & 15,179 & 5,441 & 4,625 & 5,441 & 3. 39 & 22.88 & 26.39 \\
\hline $15,9: 5$ & 17,782 & 15,316 & 5.728 & 3,342 & 5,728 & 26.47 & 15.82 & 26,47 \\
\hline 15,690 & $: 9.686$ & 16,690 & 6,023 & 2,414 & 6,029 & 26.54 & $10 . \$ 8$ & 26.54 \\
\hline 17,5$) 4$ & cl.j9g & $19,27 !$ & $6.34 c^{2}$ & 1,74 & 3,958 & 26. 60 & 7.54 & 17.04 \\
\hline 18,359 & $a 2,989$ & 21,858 & 6.668 & 1.260 & 2,533 & 26.64 & 5.20 & 10.38 \\
\hline 19,249 & 24,501 & 23.974 & 7,009 & 911 & 1,621 & c6.69 & 3.58 & 6.33 \\
\hline 20,173 & 25.968 & 25,342 & 7,362 & 658 & $M$ & ๔6. 74 & 2.47 & $\omega$ \\
\hline 21.130 & c77.411 & 26.549 & 7,728 & 475 & $M$ & 26. 78 & 1.70 & $M$ \\
\hline 22,114 & 28.847 & 27,793 & 8,108 & $3+3$ & $M$ & 26. 83 & 1.18 & $\omega$ \\
\hline 23,125 & 30,286 & 39,074 & 8,501 & 248 & $m a$ & 26.88 & 0.81 & 40 \\
\hline 24,103 & 31,736 & $=0,389$ & 8.507 & 173 & $\omega$ & 26.93 & 0.56 & $N$ \\
\hline
\end{tabular}

M. Estimate not arailable.

Notes: No return-This series assumes that the Afghan refugee population living in Pakistan and Iran remains outsioe Afgnanistan throughout the projection oerioo.

$15 x$ return-inis series assuars that the Afghan refugee population living in Pakistan and Iran Degins to return to Afgnanistan in 1990, with 15 percent of the refugees rewaining outside tie country returning each year until zolo.

201 return-This uries assumes that the Afghan refucgee population living in Pakistan and Iran begins to return to Afgunistan in 1995, with 20 percent of the refigees rewaining out side the country returning each yeur until 2000 .

Scurce: U.5. Bursat of the Cersus, unoublished component population projections, uediug fertility series. with alternative assiantions of the return of the refuges sooulation to Afghanistan. 
Table A-11. Frojected Popilation, by Age and Sex: 1385

(Population in thousarids. Figures may not add to totals due to rounding;

\begin{tabular}{|c|c|c|c|c|c|c|}
\hline \multirow[b]{2}{*}{ Age } & \multicolumn{3}{|c|}{ Fopulat lon } & \multicolumn{3}{|c|}{ Fercent } \\
\hline & $\begin{array}{r}\text { Both } \\
\text { sexes }\end{array}$ & Male & Female & $\begin{array}{l}\text { Both } \\
\text { sexes }\end{array}$ & Male & Female \\
\hline Total, & & & & & & \\
\hline all ages & $1 \equiv, 886$ & 7,197 & 6,689 & $1(10) .0$ & 100.0 & 100.0 \\
\hline 0 tis 4 years & 2,387 & 1,213 & 1,174 & 17.2 & 16.9 & 17.6 \\
\hline 5 to 3 years & 1,376 & 1,012 & 964 & 14.2 & 14.1 & 14.4 \\
\hline 10 to 14 years & 1,713 & 875 & 844 & 12.4 & 12.3 & 12.6 \\
\hline 15 t: 19 years & 1,460 & 751 & 709 & 10.5 & 10.4 & 10.6 \\
\hline 20 to 24 years & 1,255 & 657 & 598 & 9.0 & 9.1 & 8.9 \\
\hline Is to 29 years & 1,057 & 556 & 501 & 7.6 & 7.7 & 7.5 \\
\hline 30 to 34 years & 883 & 463 & 420 & 6.4 & 6.4 & 6.3 \\
\hline IJ to 33 years & 755 & 386 & 349 & 5.3 & 5.4 & 5.2 \\
\hline 41) to 44 years & 608 & 320 & 288 & 4.4 & 4.4 & 4.3 \\
\hline 45 to 49 years & 497 & 263 & 235 & 3.6 & 3.7 & 3.5 \\
\hline so to 54 years & 401 & 211 & 130 & 2.9 & 2. 9 & 2.8 \\
\hline 55 to 59 years & 314 & 166 & 149 & 2. 3 & 2.3 & 2.2 \\
\hline 60 to 64 years & 237 & 126 & 111 & 1.7 & 1.8 & 1.7 \\
\hline 65 to 69 years & 166 & 90 & 77 & 1.2 & 1.2 & 1.1 \\
\hline 70 to 74 years & 104 & 57 & 47 & 0.7 & 0.8 & 0.7 \\
\hline 75 to 79 years & 57 & 34 & 24 & 0.4 & 0.5 & 0.4 \\
\hline 80 years and over & 29 & 19 & 10 & 0.2 & 0.3 & 0.1 \\
\hline
\end{tabular}

Source: U.S. Bureau of the Census, unpublished component population projections, mediun series. 
Table A-12. Projected Populatisn, by Age and Sex: 1390

(Populatiori in thousards. Figures may not ajd to totals due to roindingl

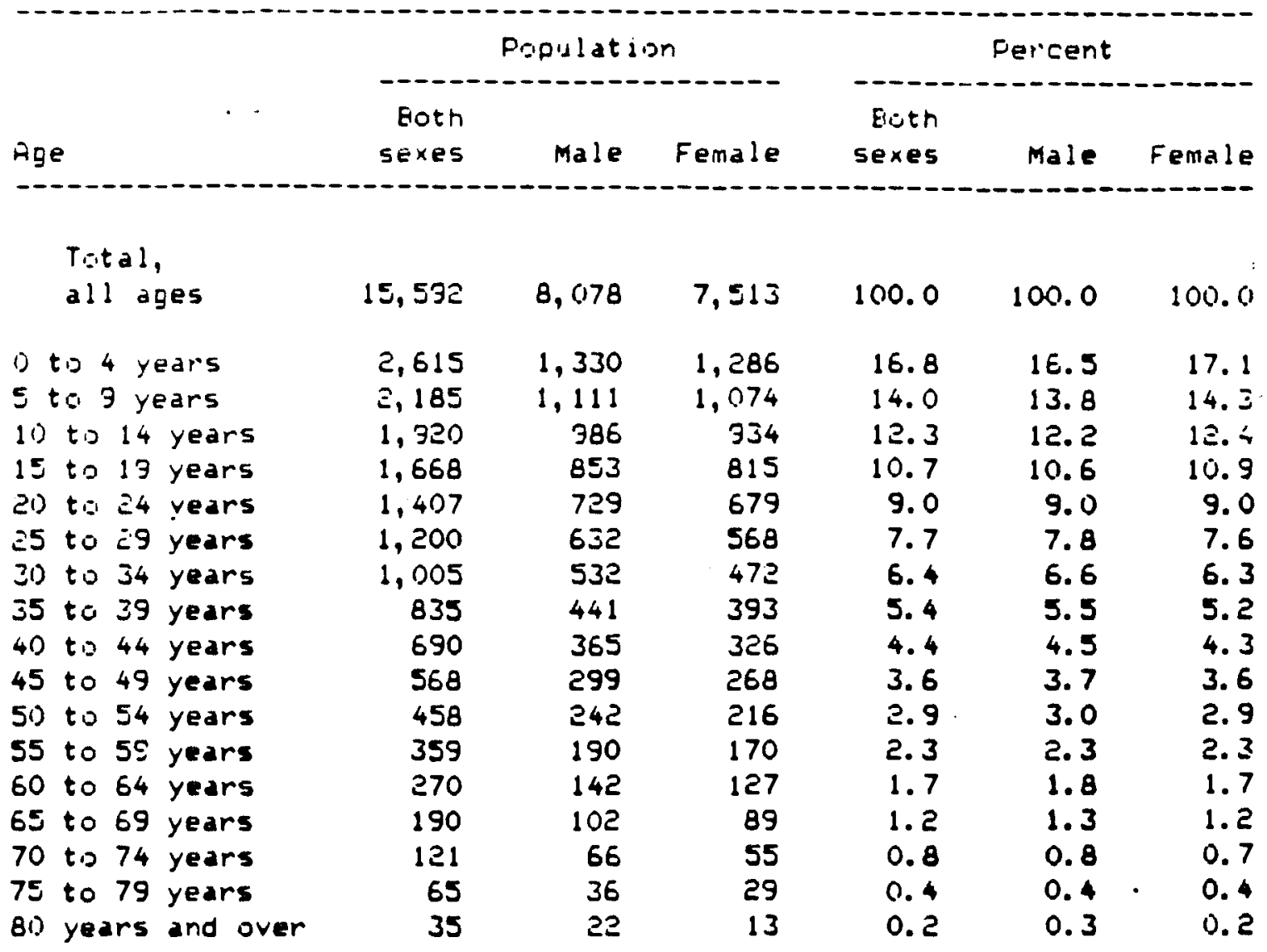

Source: U.S. Buradu of the Census, unpublished component pepulation projections, medium ssries. 
Table A-13. Projected Papilation, by Fge and Sex: 1335

(Population in thciusarids. Figures may not add to tcitals dise to rounding?

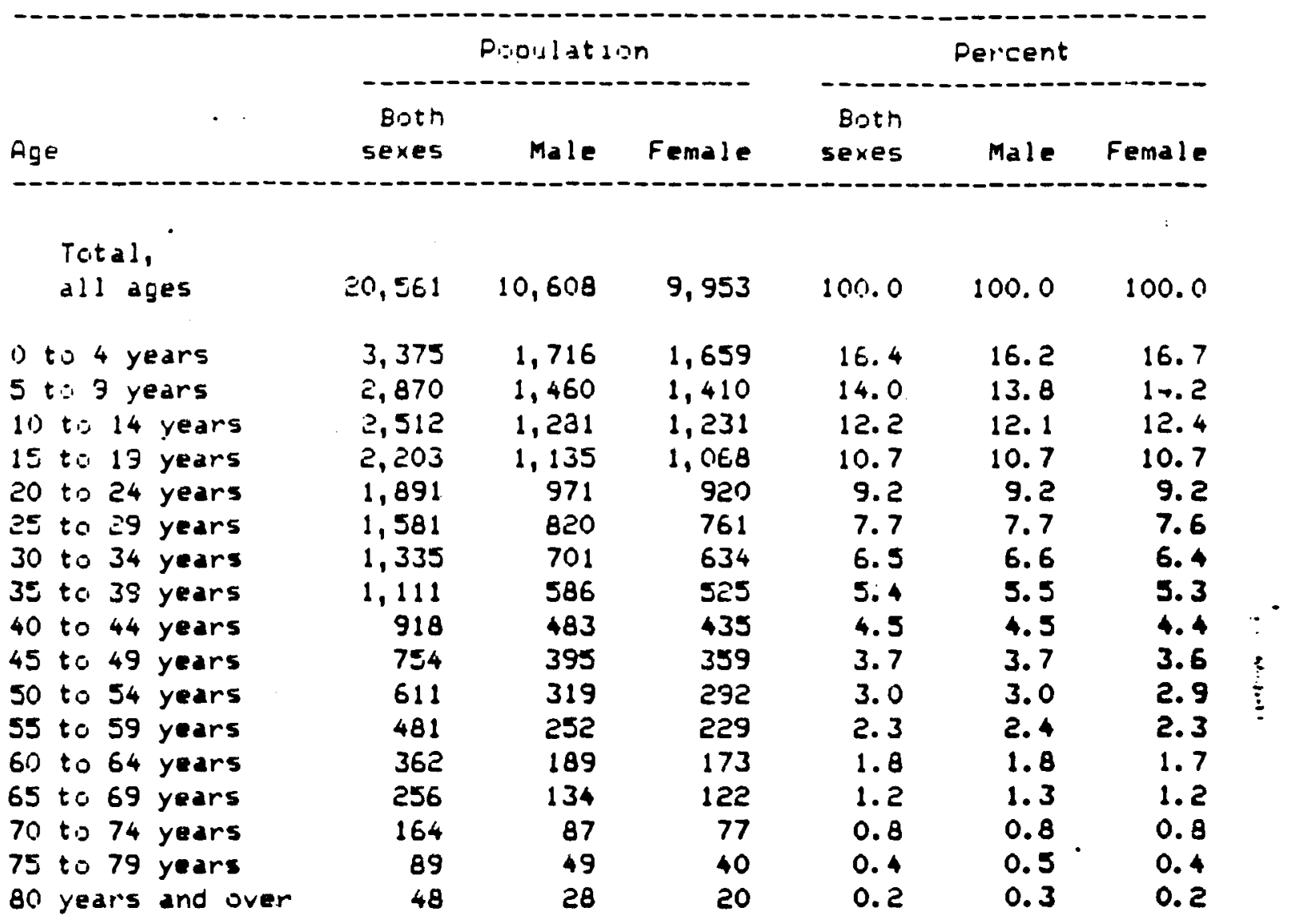

Source: U.S. Bureau of the Census, unpublished component population projections, mediun suries. 
Table A-14. Projected Popuiation, by Age and Sex: 2000?

(Population in theusarids. Figures may not add to totals due to rounding)

\begin{tabular}{|c|c|c|c|c|c|c|}
\hline & & Fopilat & & & Fercen & \\
\hline . & Both & & & Both & & \\
\hline Age & sexes & Male & Female & sexes & Male & Female \\
\hline Total, & & & & & & \\
\hline all ages & 24,501 & $12,6 \hat{z}$ & 11,878 & 100.0 & 100.0 & 300.0 \\
\hline 1) to 4 years & 3,925 & 1,997 & 1,928 & 16.0 & 15.8 & 16.2 \\
\hline 5 to 9 years & 3,359 & 1,709 & 1,650 & 13.7 & 13.5 & 13.9 \\
\hline 10 to 14 years & 2,979 & 1,513 & 1,460 & 12. 2 & 12.0 & 12.3 \\
\hline 15 to 13 years & 2,605 & 1,333 & 1,272 & 10.6 & 10.6 & 10.7 \\
\hline 20 to 34 years & 2,263 & 1,170 & 1,093 & 9.2 & 9.3 & 9.2 \\
\hline Zs to c's years $^{\prime}$ & 1,929 & 994 & 934 & 7.9 & 7.9 & 7.9 \\
\hline 31) to 34 years & 1,604 & 834 & 770 & 6.5 & 6.6 & 6.5 \\
\hline 35 to 39 years & 1,346 & 708 & 638 & 5.5 & 5.6 & 5.4 \\
\hline 40 to 44 years & 1,114 & 588 & 526 & 4.5 & 4.7 & 4.4 \\
\hline 45 to 49 years & 915 & 480 & 434 & 3.7 & 3.8 & 3.7 \\
\hline 50 to 54 years & 741 & 387 & 354 & 3.0 & 3.1 & 3.0 \\
\hline 55 to 59 years & 586 & 305 & 281 & 2.4 & 2.4 & 2.4 \\
\hline 60 to 64 years & 444 & 231 & 212 & 1.8 & 1.8 & 1.8 \\
\hline 65 to 69 years & 315 & 164 & 151 & 1.3 & 1.3 & 1.3 \\
\hline 70 to 74 years & 203 & 106 & 96 & 0.8 & 0.8 & 0.8 \\
\hline 75 to 79 years & 112 & 60 & 52 & 0.5 & 0.5 & 0.4 \\
\hline 80 years and over & $E 2$ & 35 & 26 & 0.3 & 0.3 & 0.2 \\
\hline
\end{tabular}

Source: U.S. Bureau of the Census, unpublithed component population projections, medium series. 
Table A-15. Projected Popilation, by Age and Sex: a005

(Population in theusarids. Figures may not add to totals due to rounding)

\begin{tabular}{|c|c|c|c|c|c|c|}
\hline & \multicolumn{3}{|c|}{ Pioplat 3 ion } & \multicolumn{3}{|c|}{ Fercent } \\
\hline Age & $\begin{array}{r}\text { Both } \\
\text { sexes }\end{array}$ & Male & Female & $\begin{array}{l}\text { Both } \\
\text { sexes }\end{array}$ & Male & Female \\
\hline Total, & & & & & & \\
\hline all ages & $28,1=9$ & 14,473 & 13,651 & 100.0 & 100.0 & 100.6 \\
\hline 0 tis 4 years & 4,330 & 2,203 & 2,127 & 15.4 & 15.2 & 15.6 \\
\hline 5 t: 3 years & 3,798 & 1,932 & 1,865 & 13.5 & 13.3 & 15.7 \\
\hline 10 to 14 years & 3,374 & 1,719 & 1,655 & 12.0 & 11.9 & 12.1 \\
\hline 15 to 19 years & 3,989 & $1,5 \Omega 8$ & 1,461 & 10.6 & 10.6 & 10.7 \\
\hline 20 to 24 years & 2,596 & 1,333 & 1,263 & 9.2 & 9.2 & 9.3 \\
\hline 25 to 29 years & 2,243 & 1,164 & 1,079 & 8. 0 & 8.0 & 7.9 \\
\hline 30 to 34 years & 1,901 & 984 & 917 & 6.8 & 6.8 & 6.7 \\
\hline 35 to $\Sigma 3$ years & 1,573 & $8 \overrightarrow{20}$ & 752 & 5.6 & 5.7 & 5.5 \\
\hline 41) to 44 years & 1,313 & E92 & 621 & 4.7 & 4.8 & 4.5 \\
\hline 45 to 49 years & 1,080 & 570 & 510 & 3.8 & 3.9 & 3.7 \\
\hline 50 to 54 years & 874 & 458 & 416 & 3.1 & 3.2 & 3.0 \\
\hline 55 to 59 years & 693 & 361 & 332 & 2.5 & 2.5 & 2.4 \\
\hline 60 to 64 years & 528 & 274 & 254 & 1.9 & 1.9 & 1.9 \\
\hline 65 to 63 years & 378 & 196 & 182 & 1.3 & 1.4 & 1.3 \\
\hline 70 to 74 years & 246 & 128 & 118 & 0.9 & 0.9 & 0.9 \\
\hline 75 to 79 years & 137 & 73 & 65 & 0.5 & 0.5 & 0.5 \\
\hline 80 years and over & 77 & 43 & 34 & 0.3 & 0.3 & 0.2 \\
\hline
\end{tabular}

Source: U.S. Bureau of the Census, unpublished component population projections, medium series. 
Tatle A-lí. Projected Pooulation, by Age and Sex: Ello

(Population in theiusarids. Figures may not add to totals dise to roinding)

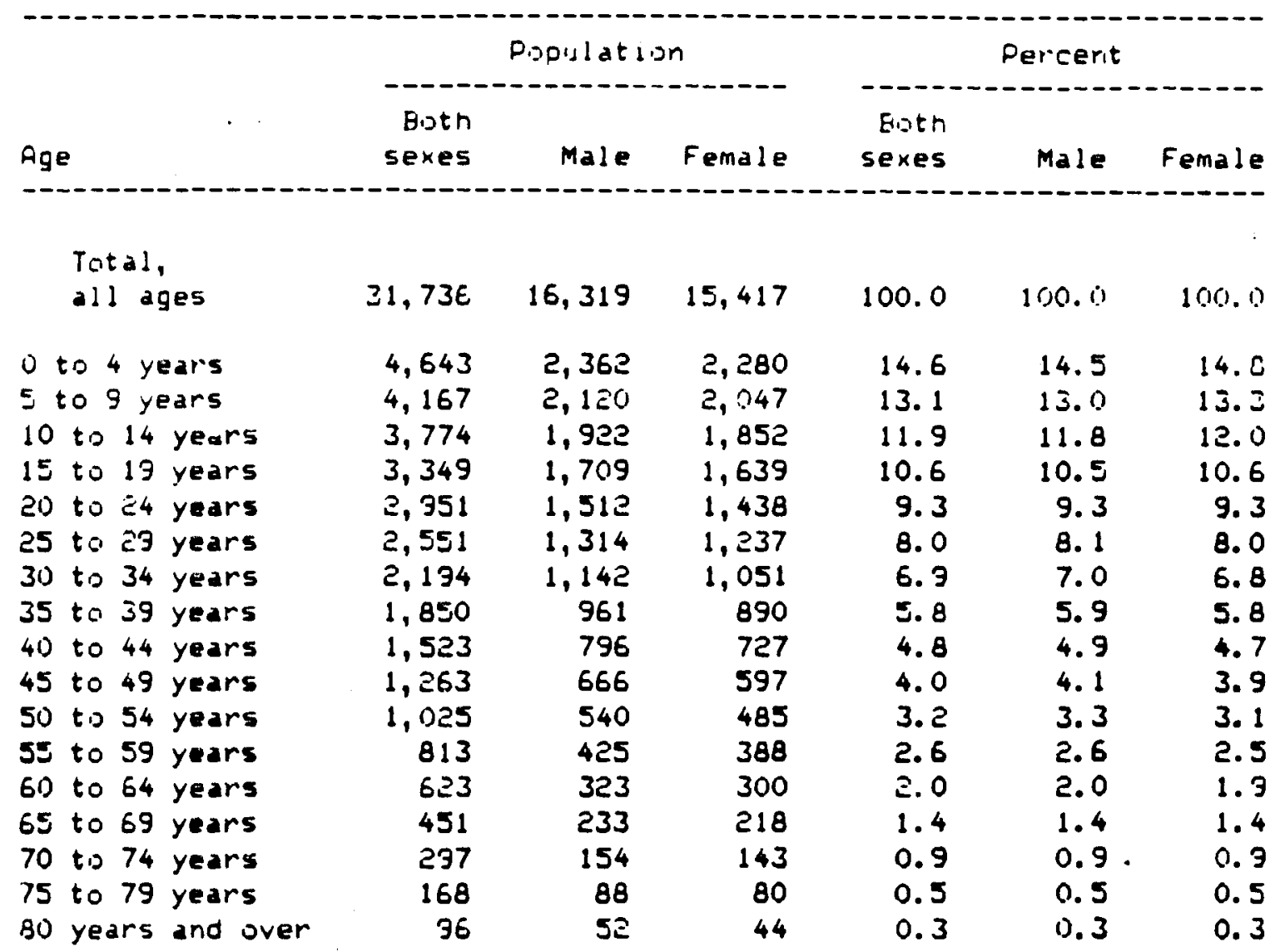

Source: U.S. Bureau of the Census, unpublished component population projections, medium series. 
Afghanistan Central Statistics office. 1981. Preliminary Results of the First Afghan Population Census. Publication No. (1). Kabul.

T.KabulT.

- 1982. Economic and Social Indicators: March 1979-1982.

- 1983. Statistical Year Book 1360. Kabul.

Afghanistan Central Statistics office and U.S. Agency for International

nevelopment. 1975a. National nemographic and Family Guidance Survey of the Settled Population of Afghanistan. Vol. l. Demography and Knowledge. At itudes and Practices of Family Guidance. [Kabul].

- 1975b. National Demographic and Family Guidance Survey of the Settled Population of Afghanistan. Vol. 2. Methodology. [Kabul].

- 1975c. National Demographic and Family Guidance Survey of the Settled Population of Afghanistan. Vol. 3. Tables. [Kabul].

Afghanistan State Planning Committee. 1985. Socio-Economic Development Plan of the Democratir Republic of Afghanistan for the Year 1364 (1985-86). Kabul.

Coale, Ansley J. and paul Demeny. 1966. Regional Model Life Tables and Stable Populations. Princeton University. Princeton.

Shalikar, Mohtasham. 1983. Estimation of Basic nemographic Parameters and an Assessment of the Afghanistan Census of 1979. UnpubTished Master's thesis.

United Nations. 1985. Demographic Yearbook 1983. New York

- 1986. Worlo Population Prospects: Estimates and Projections as

Assessed in 1984. ST/ESA/SER.A/98. New York.

United Nations High Commissioner fo. Refugees (UNHCR). 1980. Humanitarian Assistance Programme to Afghan Refugees in Pakistan (Situation as of 31 Octoder, 1980). Report No. 9. Unpublished.

- 1981a. Humanitarian Assistance Programe to Afghan Refugees in Pakistan: Situation as of 28 February, 1981. Report No. 10. Unpublished.

- 1981b. Refugee Update. No. 48. Unpuhlitshed.

- 1981C. UNHCR Humanitarian Assistance Programe to Afghan Refugees in Pakistan: Situation as of 31 May 1981. Report No. 11. Is lamabad. 
11.S. Agency for International nevelopment. 1976. Rasic Health Services: Afghanistan. Project Paper. Unpublished.

U.S. Rureau of the Census. 1978. Afghanistan: A Demographic lincertainty, by James $F$. Spitler and Nancy R. Frank. International Research Document No. 6. washington, D.r.

- 1984. "Detailed Statistics on the Urban and Rural Population of Pakis: 1950 to 2010," by Glenda S. Finch, Paul R. Campbell, and James F. Spitler. unpublished.

U.S. Committee for Refugees. 1982. Afghan Refugees in Pakistan: Will They Go Home Again?, by Allen K. Jones. New York.

New York.

- 1985. Afghan Refugees: Five Years Later, by Allen K. Jones.

U.S. Department of State, Rureau of Public Affairs. 1986. Afghanistan: Seven Years of Soviet Occupation, by Craig Karp. Special Report No. 155. Washington, D.C.

U.S. Department of State, Rureau of Refugee Programs. 1982. Personal communisztion.

- 1986. Personal communication.

World Health Organization and Afghanistan Ministry of Public Health. 1980 . Infant and Early Childhood Mortality in Relation to Fertility Patterns: Report on an Ad-HoC Survey in Greater Kabul 1972-1975. Kabul. 


\section{Un olari rapers}

is. i2 Bibliography of Soviet Statistical Handbooks, by

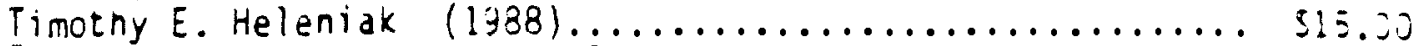

[updated version of SP No. 3]

No. 41 USSR: Estimates and Projections of the

Population by Major Nationality, 1979 to 2050,

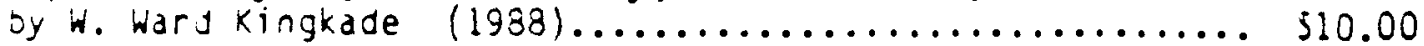

No. 40 Family Planning in China: Recent Trends, by

Karen Hardee-Cleaveland and Judith Banister (1988)....... \$10.00

No. 39 Indonesia: An Overview of Selected Socioeconomic

Subjects, by Kathleen Short $(1988) \ldots . . \ldots \ldots . . . \ldots . . . . \$ 10.00$

No. 38 The Soviet View on the State of Technological Innovation

in the USSR, by Louvan E. Nolting (1988)............... \$10.00

No. 37 USSR: The Brigade System of Labor Organization

and Incentives in Industry and Construction, by

Meredith M. Heinemeier (1988)........................ \$ 5.00

No. 36 USSR: Trends in Fuel and Energy Consumption by

Sector and Fuel, 1970-1980, by Matthew J. Sagers and

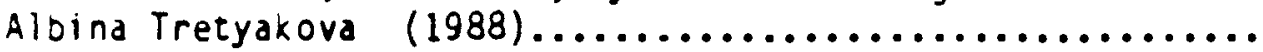

$\$ 10.00$

No. 35 Aging in the Third World, by Kevin G. Kinselld (1988).....\$ \$10.00

No. 34 Afghanistan: A Demographic Profile, by

Frank B. Hobbs (1988).............................. \$10.00

No. 33 Estimates and Projections of the Population of the USSR:

1979 to 2025, by W. Ward Kingkade (1987)............... \$10.00

No. 32 USSR: Motor Fuel Use and Conservation in Transportation

and Agriculture, 1970 to 1984, by Albina Tretyakova and

Barry Kostinsky (1987).

$\$ 10.00$

No. 31 China: Consumer Demand Statistical Update, by

Jeffrey R. Taylor (1987).

$\$ 15.00$

No. 30 USSR: Energy Consumption in the Housing and

Municipal Sector, by Matthew J. Sagers and Albina

Tretyakova (1987).

5.00

No. 29 USSR: Energy Consumption in the Chemical,

Petrochemical, and Petroleum Refining Industries, by

Matthew J. Sagers and Albina Tretyakova (1987)........... \$ 5.00

No. 28 Fuel and Energy Use in the Soviet Metallurgy Industries,

by Matthew J. Sagers and Albina Tretyakova (1987)......... \$10.00

No. 27 Future Implications of Alternative Family Planning

Policies in China, by John S. Aird

(1986).

$\$ 5.00$ 
vo. 25 Scientists and Engineers in Industrialized Countries:

A Comparison of Characteristics for France, West

Germany, Japan, the United Kingdom, and the United

States, by Peter 0 . Way and Ellen Jamison (1986)........ \$15.30

No. 25 Central American Migration: Past and Present,

by Linda S. Peterson (1986)....................... \$10.00

No. 24 A Bibliography of National Income Accounting in China,

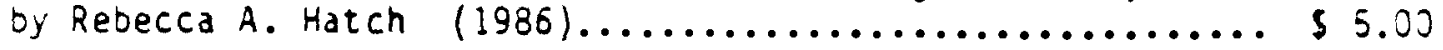

No. 23 China: Recent Trends in Health and Mortality, by

Judith Banister (1986)........................... \$10.00

No. 22 China's Price Structure in International Perspective,

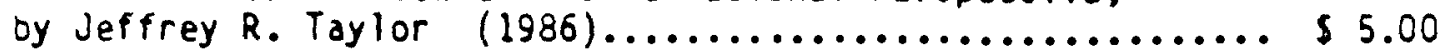

No. 21 Demographic Estimates, Projections, and Selected

Social Characteristics of the Population of India, by

Frank B. Hobbs (1986)..............................\$10.00

No. 20 Cost Estimates for the Soviet 011 Industry: 1970 to

1990, by Albina Tretyakova and Meredith Heinemeler (1986).

$\$ 10.00$

No. 19 Cost Estimates for the Sovtet Gas Industry: 1970 to

1990, by Albina Tretyakova and Meredith Heinemeter (1986)

$\$ 10.00$

No. 18 Cost Estimates for the Soviet Codl Industry: 1970 to

1990, by Albina Tretyakova and Meredith Heinemeier

$(1986)$

$\$ 10.00$

No. 17 Soviet Foreign Trade in Foodstuffs: A Calorie Measure, by Vladimir G. Trem

$(1986)$

$\$ 10.00$

No. 10 Employment Outlook for China to the Year 2000, by

Jeffrey R. Taylor

(1986)

$\$ 5.00$

No. 15 Urban-Rural Population Projections for China, by Judith Banister (1986)

Report only.

$\$ 10.00$

Report with medium projection printout..................

Report with high, medium, and low projection printouts....

$\$ 12.50$

$\$ 16.50$

No. 14 Natural Gas Liquids and the Soviet Gas Prucessing

Industry, by Matthew J. Sagers (1986)

$\$ 10.00$

No. 131977 Consumption by Industrial Sector of the USSR, by Meredith Helnemeler

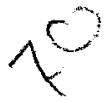


10. Il The Freight Rate Structure on Soviet Railroads, oy

Matthew J. Sagers and Milford 8. Green (1985)............ 5 5.3.

io. 10 Civilian Employment in the USSR: 1950 to 1333,

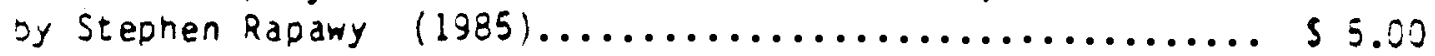

No. $\exists$ Evaluation of Selected Soviet Population Statistics,

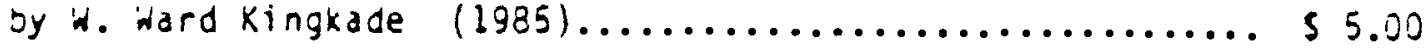

No. 8 Reestimation of Gross Value of Industrial Output oy

Branch of Production for the People's Repuolic of

C.ina, 1952-1957, by Jeffrey R. Taylor (1983).......... ; 5.00

No. 7 Components of Gross Investment in 1966 and 1972

Soviet Input-Output Tables, by James W. Gillula (1984)..... \$ 5.00

No. 6 Issues and Implications of the Aging Japanese

Population, by Peter 0. Way $(1984) \ldots . . . \ldots . . . . . . . . . \$ \$ 10.00$

No. 5 A Compendium of Soviet Health Statistics, by

Murray Feshbach (1985).............................\$10.00

No. 4 Restructuring the Soviet Petroleum Refinting Industry,

by Matthew Sagers and Albina Tretyakova (1985)...........\$10.00

No. 3 Bioliography of Regional Statistical Handbooks in See SP the USSR, by Meredith M. Heinemeter (1984)............. No. 12

No. 2 Refinery Throughput in the USSR, by

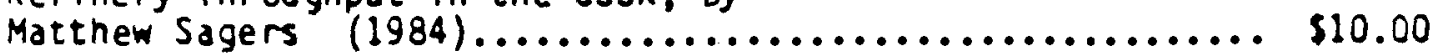

No. 1 Construction of a 1977 Input-Output Table, by

Dimitri M. Gallik, et al. (1984).....................\$ \$10.00
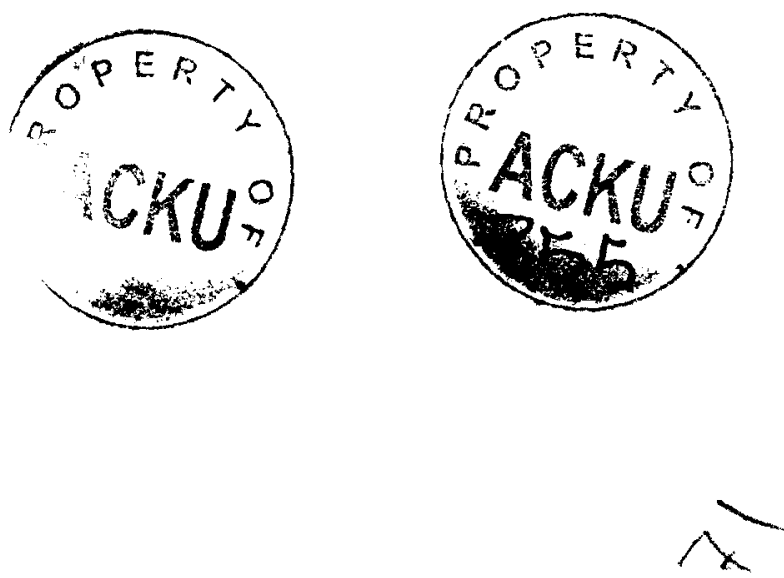